\title{
LAW AND FINANCE IN EMERGING ECONOMIES: GERMANY AND BRITAIN 1800-1913
}

\author{
Carsten Gerner-Beuerle*
}

\begin{abstract}
By most standards, Britain in the $19^{\text {th }}$ century was the leading financial nation in the world, possessing more developed capital markets than any other country. An influential view in the law and finance literature argues that holding macroeconomic factors constant, this difference in financial development can be attributed to more stringent disclosure regulation in Britain. This article compares Britain with another European country that was at the centre of the industrial transformation in the $19^{\text {th }}$ century: Germany. It presents a more granular analysis of regulatory reform than is available elsewhere in the literature and presents findings that are, in several respects, at variance with the orthodox view in law and finance. The level of disclosure regulation was largely comparable in both countries during the period under investigation. Furthermore, reform of disclosure regulation was not an exogenous stimulus of financial development, but evolved incrementally and in response to changing market conditions. This was different with respect to the legal regime governing the formation of stock corporations. Here, the two countries developed in diametrically opposed directions as a result of concerted efforts by the policy maker to effect changes in market conditions. The article argues that these rules stand out as the most striking difference between Germany and the UK, a difference that was relevant to organisational choice and types of finance available to the entrepreneur.
\end{abstract}

Keywords: Law and finance; financial development; disclosure regulation; private enforcement; liability for incorrect disclosures

\footnotetext{
* Law Department, London School of Economics and Political Science. I am grateful to John Armour, Markus Baltzer, Theodor Baums, Klaus J. Hopt, David Kershaw, Gerhard Kling, Michael Lobban, Eva Micheler, Federico Mucciarelli, Wolf-Georg Ringe, the anonymous reviewers of the Modern Law Review, and the participants of conferences and seminars at the University of Bonn, Chinese University of Hong Kong, London School of Economics, SOAS, and the University of Warwick for valuable comments. All mistakes are mine.
} 


\section{INTRODUCTION}

A perennial concern of policy makers around the world is the construction of a framework of financial regulation that is effective, efficient, and-most importantly-conducive to the emergence of deep and liquid financial market. While the channels through which financial development influences economic growth are not yet fully understood, there is broad agreement that developed financial markets are instrumental in fostering economic growth. ${ }^{1}$ Thus, the importance of regulatory design for the prosperity of nations can hardly be overestimated.

Essential ingredients of any regulatory regime governing the capital markets are rules mandating the disclosure of financial information, both transaction-specific and ongoing, and liability rules that allow investors to recover losses from those who are responsible for misstatements to the market. Legal institutions requiring, for example, the disclosure of the company's annual accounts and the publication of an offering prospectus containing particulars of the company and the securities to be offered to the public were formulated, for the first time, in the $19^{\text {th }}$ century. This period saw the transformation of largely agrarian economies to industrial ones, first in Western Europe and then in the United States. With it came the mobilization of capital, expansion of the banking system, and increased use of the capital markets as a means of financing industrial enterprises. ${ }^{2}$

One country was ahead of all other industrialising nations in terms of financial development over the course of the $19^{\text {th }}$ century: Great Britain. The number of joint stock companies incorporated in Britain was seven to eight times higher and their paid-up capital three to four times larger than in the next largest economies on the Continent, ${ }^{3}$ and the London Stock Exchange was the leading exchange in the world, with a deeper and more liquid market than anywhere else. ${ }^{4}$ The different financial trajectory is particularly astonishing when compared

\footnotetext{
${ }^{1}$ The first in-depth consideration of the nexus of finance and economic growth is commonly attributed to Joseph Schumpeter, The Theory of Economic Development: An Inquiry into Profits, Capital, Credit, Interest, and the Business Cycle (Harvard University Press, 1911). For two more recent contributions providing empirical evidence see Robert G. King and Ross Levine, 'Finance and Growth: Schumpeter Might Be Right' (1993) 108 Q. J. Econ. 717; Raghuram G. Rajan and Luigi Zingales, Financial Dependence and Growth' (1998) 88 Am. Econ. Rev. 559.

${ }^{2}$ Caroline Fohlin, Mobilizing Money (CUP, 2012) 15-47.

${ }^{3}$ In 1906, 40,995 joint-stock companies with a combined paid-up capital of $£ 2,000$ million were incorporated in Britain, compared with 5,061 companies with a paid-up capital of $£ 685$ million in Germany (also 1906) and 6,325 companies with a paid-up capital of $£ 540$ million in France (1898), see Ranald Michie, 'Different in name only? The London Stock Exchange and foreign bourses, c. 18501914' (1988) 30 Business History 46, 52.

${ }^{4}$ Ranald Michie, The London Stock Exchange: A History (OUP, 2001) 70-73. For comparative data on stock market capitalisation and the number of listed companies per million people see also Raghuram
} 
with another European economy that was rapidly growing in the latter half of the $19^{\text {th }}$ century and overtook Britain as the leading industrial powerhouse of Europe by the early $20^{\text {th }}$ century: Germany. In spite of the fact that Germany was home to a considerable number of expanding industrial corporations, available comparative data show consistently that, until the eve of World War I, Germany's financial markets lagged behind those in Britain in respect of almost every measure of financial development: number of incorporated firms, number of listed firms, volume of securities issues, stock market capitalization as a percentage of gross domestic product, and financial assets as a proportion of national assets. ${ }^{5}$

One explanation of these striking differences in financial development, often advanced in the law and finance literature, is epitomised by the following quote:

"Disclosure legislation by the end of the nineteenth century armed British investors ... with the best information possessed by investors anywhere. We consider this to be a reason, possibly a major reason ... why the British capital markets were the world leaders in the same era."

The central role for financial development that this view attributes to disclosure regulation, and more generally to investor protection laws as promulgated in common law countries, has been challenged by a number of studies that have forcefully argued that investor protection in $19^{\text {th }}$ century Britain was not substantial. ${ }^{7}$ However, both sides in the debate focus generally

G. Rajan and Luigi Zingales, 'The Great Reversals: The Politics of Financial Development in the 20th Century’ (2003) 69 J. Fin. Econ. 5, 15.

${ }^{5}$ For data on Germany, see Deutsche Bundesbank, Deutsches Geld- und Bankwesen in Zahlen, 18761975 (Knapp, 1975), 287-296; Richard van der Borght, Statistische Studien über die Bewährung der Actiengesellschaften (Gustav Fischer, 1883); Ernst Engel, 'Die erwerbsthätigen juristischen Personen im preussischen Staate, insbesondere die Actiengesellschaften’ (1875) 15 Zeitschrift des Königlich Preussischen Statistischen Bureaus 449. Annual information on listings on the London Stock Exchange are contained in Burdett's Official Intelligence of Securities (Couchman, from 1882), later renamed Stock Exchange Official Intelligence. Sources presenting comparative data include George W Edwards, The Evolution of Finance Capitalism (Longmans, 1938) 392-393, 404-405; Raymond W Goldsmith, Comparative National Balance Sheets: a Study of Twenty Countries 1688-1978 (University of Chicago Press, 1985) 221-226; Leslie Hannah, "The "Divorce" of Ownership from Control from 1900 Onwards: Re-calibrating Imagined Global Trends' (2007) 49 Business History 404, 406; Alfred Neymarck, 'La statistique internationale des valeurs mobilières' (1915) 56 Journal de la Société Française de Statistique 353, 360-366.

${ }^{6}$ Richard Sylla and George David Smith, 'Information and Capital Market Regulation in AngloAmerican Finance' in Michael D Bordo and Richard Sylla (eds.), Anglo-American Financial Systems: Institutions and Markets in the Twentieth Century (Irwin, 1995) 179. Similar views are expressed in the well-known studies of Rafael La Porta, Florencio Lopez-de-Silanes, Andrei Shleifer, and Robert Vishny (LLSV), e.g. LLSV, 'Legal determinants of external finance' (1997) 52 J. Fin. 1131; Rafael La Porta, Florencio Lopez-de-Silanes, and Andrei Shleifer, 'The Economic Consequences of Legal Origins' (2008) 46 J. Econ. Lit. 285.

${ }^{7}$ Graeme G Acheson et al., 'Corporate ownership and control in Victorian Britain' (2015) 68 Economic History Review 911; Brian R Cheffins, 'Does Law Matter? The Separation of Ownership and Control in the United Kingdom' (2001) 30 Journal of Legal Studies 459; Brian R Cheffins, Corporate Ownership and Control: British Business Transformed (OUP 2008), 194-197; Julian Franks, Colin Mayer and Stefano Rossi, 'Ownership: Evolution and Regulation' (2009) 22 Rev. Finan. Stud. 4009. 
only on major legislative reforms and do not map the evolution of disclosure regulation at a granular level and by comparing key legal systems, such as Britain and Germany. In addition, they do not consider other aspects of a country's legal system that potentially facilitate or stymie the access of entrepreneurs to capital markets in order to raise finance from public investors, notably the ease with which companies can be incorporated. ${ }^{8}$

This article contributes to the debate in two ways. First, it examines the evolving disclosure framework, as well as the evolution of legal institutions imposing liability for incorrect disclosures to the market, during the formative stages of the capital markets in Europe- the $19^{\text {th }}$ century. Even though the regulatory framework was incomplete by modern standards, legal concepts such as prospectus disclosure or liability for incorrect statements to the market that continue to constitute essential building blocks of securities regulation to this day began to emerge in a fairly well-defined form as early as the second half of the $19^{\text {th }}$ century. By analysing primary and secondary legal sources, including court decisions, parliamentary records, and contemporary contributions from legal academia, the article explores the interdependence between legal reform and stock market development. ${ }^{9}$ It discusses how changing economic conditions influenced legislative reform and the interpretation of traditional common law concepts by the courts, resulting in an incremental and endogenous evolution of disclosure regulation in both the United Kingdom and Germany. In the two countries, policy makers and the courts found similar answers to the lack of transparency and misinformation of the public that characterised the early capital markets, and it is difficult to argue that one system was clearly superior to the other in the protection it offered investors.

Second, the article highlights the fundamentally different approach in the two countries to the basic structural setup of corporations and the conditions that had to be satisfied for their

\footnotetext{
${ }^{8}$ Arguably, Britain's comparative advantage in facilitating access to equity capital cannot be explained with the 'maturity' of the financial markets, i.e. the experience and rational behaviour of investors and other market actors. Financial crises occurred both in Germany and the UK in the second half of the $19^{\text {th }}$ century and the London stock market was by no means free from market imperfections, see Philip L Cottrell, 'Domestic finance, 1860-1914' in Roderick Floud and Paul Johnson (eds.), The Cambridge Economic History of Modern Britain, vol. 2 (CUP, 2004), 253, 277-279.
}

${ }^{9}$ A number of studies in finance and economics analyse the wider economic and regulatory landscape in $19^{\text {th }}$ century Germany to assess the effect of changing legal and non-legal conditions on ownership structure and financing patterns. See, for example, Carsten Burhop, David Chambers and Brian R Cheffins, 'Law, Politics and the Rise and Fall of German Stock Market Development, 1870-1938' (2015) ECGI Law Working Paper No. 283/2015; Caroline Fohlin, 'The History of Corporate Ownership and Control in Germany' in Randall K Morck (ed.), A History of Corporate Governance around the World: Family Business Groups to Professional Managers (University of Chicago Press, 2005), 223 [hereinafter Fohlin, 'History']; Caroline Fohlin, Finance Capitalism and Germany's Rise to Industrial Power (CUP, 2007), in particular 15-47; Julian Franks, Colin Mayer and Hannes F Wagner, 'The Origins of the German Corporation - Finance, Ownership and Control' (2006) 10 Rev. Fin. 537. However, again, these studies do not provide for a detailed analysis of the applicable legal environment. 
formation. As opposed to disclosure regulation, these rules did not evolve incrementally, but in fits and starts, with wide-ranging liberalisation in the 1840s in the United Kingdom and in the 1870s in Germany, and less than two decades later a substantial reversion to a more paternalistic regime that effectively excluded large sections of the population from the capital markets in Germany, but not in the United Kingdom. These reforms had a well-documented effect on economic concentration ${ }^{10}$ and the choice of organisational form by German entrepreneurs, ${ }^{11}$ but they have received virtually no consideration in the law and finance literature.

The article, therefore, fills a gap in the literature by providing a detailed comparative analysis of important building blocks of the legal environment pertaining to the corporate economy during a period that saw the contemporaneous emergence of liquid capital markets and modern concepts of securities regulation. The analysis allows us to identify where German and English law differed, and where the regulatory regime was similar and therefore has little power in explaining the different trajectories of financial development. At the same time, it is important to recognise the limitations of the analysis. In order to come to robust conclusions regarding the causal effect of the legal institutions examined here on the development of financial markets, it would be necessary to control for all potentially relevant explanatory variables, including economic variables such as the more or less capital-intensive nature of the industries seeking to raise finance at different stages of industrialisation ${ }^{12}$ or the

${ }^{10}$ Franks, Mayer and Wagner, n 9 above, 538; Norbert Reich, 'Auswirkungen der deutschen Aktienrechtsreform von 1884 auf die Konzentration der deutschen Wirtschaft' in Norbert Horn and Jürgen Kocka (eds.), Law and the Formation of the Big Enterprises in the $19^{\text {th }}$ and Early $20^{\text {th }}$ Centuries (Vandenhoeck \& Ruprecht, 1979), 255, 263-265.

${ }^{11}$ Timothy Guinnane et al., 'Putting the Corporation in its Place' (2007) 8 Enterprise \& Society 687, 702 (tracing the organisational choices between public corporations, partnerships limited by shares, private limited companies, limited partnerships, and general partnerships in Prussia from 1867-1932, and showing that the formation of public corporations as a percentage of all newly established firms increased with the liberalising reforms of 1870 and decreased with the restrictive later reforms, which date from 1884).

${ }^{12}$ For example, according to the so-called Gerschenkron hypothesis, the reason for the dominance of bank financing in Germany, rather than the raising of funds in capital markets, is seen in the position of the German economy as a relative latecomer among industrializing nations (or, to put it differently, in Germany's moderate economic backwardness at the time). Industrialization, it is argued, unfolded rapidly in Germany because companies were able to adopt technologies that had already been developed elsewhere. However, rapid expansion and technological transformation required vast sums of money that could not easily be mobilized except by large, financially powerful banks. In first-mover countries such as the UK that experienced more incremental industrialization, on the other hand, it was possible to finance industrial development through the reinvestment of profits and the offering of shares to the public, including to small savers. The Gerschenkron hypothesis goes back to the work of Alexander Gerschenkron, in particular his books Economic Backwardness in Historical Perspective (Harvard University Press 1962) and Continuity in History and Other Essays (Harvard University Press 1968). For an overview of the literature discussing Gerschenkron hypothesis, see Caroline Fohlin, 'Universal Banking in Pre-World War I Germany: Model or Myth?' (1999) 36 Explorations in Economic History 305, 307-314. 
availability of bank finance. ${ }^{13}$ These questions are beyond the scope of this article. Thus, the article can be seen as a stepping stone towards a broader research agenda in law and finance that acknowledges the role of both disclosure regulation and formation law and embraces a granular analysis of legal institutions that reveals how they evolve: incrementally and in response to changing market conditions, or as a concerted effort of the policy maker to effect changes in market conditions.

The remainder of this article is structured as follows. The next section analyses the evolution of disclosure regulation in Germany and the United Kingdom, focussing on the two most important items of disclosure in the $19^{\text {th }}$ century, the company's financial accounts and the offering prospectus. Section II examines the development of mechanisms to enforce disclosure obligations, which consisted, in the absence of a strong public regulator of the financial markets, ${ }^{14}$ primarily in litigation by investors who claimed that they had bought shares in reliance on incorrect information. We will see that the courts were ingenious in utilising and modifying common law concepts predating the emergence of capital markets under the impression of changing conceptions of the function of disclosure and the shift from face-to-face transactions to trading in public markets. Section III shows that, as opposed to disclosure regulation, which evolved similarly in Germany and the United Kingdom, the German legislator took the decision to reform company law fundamentally in 1884 in response to the first major stock exchange crash in Germany, making the formation of joint stock companies significantly more costly than in the United Kingdom. The more stringent formation regime, together with a high minimum nominal share value, was explicitly seen as a-somewhat crude-investor protection device, because it made investing in shares unattractive for all but the most affluent and experienced investors. I conclude by arguing that formation law, rather than disclosure regulation, stands out as the most striking difference between Germany and the United Kingdom during the formative stages of financial development, a difference that was relevant to organisational choice and types of finance available to the entrepreneur.

\footnotetext{
${ }^{13}$ It has been argued that banking institutions in the UK neglected financing the domestic industry and instead focused on other types of investment to deploy their capital, notably foreign business ventures, Bernard Elbaum and William Lazonick, 'The Decline of the British Economy: An Institutional Perspective' (1984) 44 Journal of Economic History 567, 570.

${ }^{14}$ Public enforcement was generally limited to the supervision of the operations of stock exchanges by a state commissioner (see, for example, the German Stock Exchange Act [Börsengesetz] of 22 June 1896, RGB1. 1896, p. 157, s. 2), unless the stock exchange was set up as a self-regulatory organization, Michie, $\mathrm{n} 4$ above, 35.
} 


\section{EXPERIMENTS IN ECONOMIC LIBERALISM: DISCLOSURE REGULATION}

Disclosure has long been seen by regulators and policy makers as one of the cornerstones of modern securities regulation. Today, it seems to be widely accepted that some form of mandatory disclosure, enabling potential investors to make informed decisions, plays an important role in allocating capital to productive uses and supporting the stability of financial markets. ${ }^{15}$ In the $19^{\text {th }}$ century, regulation took the first, albeit often hesitant, steps towards developing this disclosure paradigm.

\section{Germany}

The regulatory environment in early $19^{\text {th }}$ century Germany was fragmentary. While it was common for corporations to publish prospectuses describing the company's objects in order to attract investors, the law did not provide for any specific requirements regarding the form of such prospectuses. In one of the first German-language monographs dealing with the law of the joint stock corporation, the author defined a public offering prospectus as 'the announcement of the business project'. ${ }^{16}$ The legal qualification of prospectuses was not (yet) informed by any disclosure rationale, but centred on the question of whether the announcement was sufficiently certain and detailed to be capable of giving rise to contractual obligations. Insofar as the prospectus contained information about the objects and constitution of the company, the founders were bound by the disclosed facts in relation to subscribers for the company's shares. The binding effect of the prospectus encompassed 'all material facts ... all aspects which must be assumed to have influenced the decision of those who invested in the company as a result of the published prospectus. ${ }^{17}$ It was clear that the prospectus had to be analysed through a contractual lens. If statements were important for the investor's decision, they became 'material elements' of the subscription agreement, and those who were parties to the agreement could be held liable if the statements were incorrect. Outside the circle of persons bound by contract or quasi-contract, and where the prospectus contained

\footnotetext{
${ }^{15}$ From the literature, see, e.g., John C Coffee, 'Market Failure and the Economic Case for a Mandatory Disclosure System' 70 Va. L. Rev. 717 (1984); Allen Ferrell 'The Case for Mandatory Disclosure in Securities Regulation Around the World' (2007) 2 Brook. J. Corp. Fin. \& Com. L. 81. However, in spite of the almost universal agreement by policy makers, the mandatory disclosure paradigm continues to attract academic criticism, see Omri Ben-Shahar and Carl E Schneider, 'The Failure of Mandated Disclosure' (2011) 159 U. Pa. L. Rev. 647.

${ }^{16}$ Meno Pöhls, Das Recht der Actiengesellschaften (Hoffmann und Campe 1842), 20. A similar interpretation can still be found after the abolishment of the concession system in 1870, Achilles Renaud, Das Recht der Actiengesellschaften (2nd ed., Tauchnitz, 1875), 217 (referring to Pöhls).

${ }^{17}$ Pöhls, n 17 above, 155.
} 
only general statements, it did not entail any legally binding effects. ${ }^{18}$ Likewise, given that the prospectus was seen as falling within the realm of contract and not as a tool to ensure market transparency, it is not surprising that the law during the early years of German capital markets did not specify any minimum content or, in fact, require the publication of a prospectus. The only disclosure obligation contained in early laws, for example in the Prussian Stock Corporation Act of 1843, was the requirement to file the articles of association, which were then published in the official gazette. ${ }^{19}$

German corporate law was transformed from a state concession system to a system providing for incorporation by registration in $1870 .{ }^{20}$ The German legislator acknowledged that a concession system was not only incapable of protecting the public effectively, but was prone to increasing the risks for investors by giving them a false sense of confidence in the prospects of the business and thus encouraging imprudent investment behaviour. The only viable solution, it was argued, was reliance on the investors' own vigilance and care in making investments. ${ }^{21}$ However, the Companies Act of 1870, arguably, only embraced one

${ }^{18}$ Ibid. 155-158. It required some ingenuity on the part of the courts to overcome this purely contractual conception of prospectuses, see the discussion below, text to notes 77-84.

${ }^{19}$ Gesetz über die Aktiengesellschaften, Gesetz-Sammlung für die Königlich-Preußischen Staaten [Collection of Laws of the Royal Prussian State] 1843, p. 341, ss. 2-3.

${ }^{20}$ The new system was introduced for the states of the North German Confederation, which included Prussia, in Art. 211 Allgemeines Deutsches Handelsgesetzbuch (ADHGB) [General German Commercial Code], as amended by Gesetz, betreffend die Kommanditgesellschaften auf Aktien und die Aktiengesellschaften [Act Concerning Limited Partnerships by Shares and Joint Stock Corporations], BGB1. Norddt. Bund [Federal Law Gazette of the North German Confederation] 1870, p. 375. Some German states, in particular the Hanseatic cities of Bremen, Hamburg, and Lübeck, but also Württemberg and Saxony, abolished the concession system earlier than 1870, making use of the authority under art. 249 General German Commercial Code of 1861. For a full list of the respective state laws, see Stenographische Berichte über die Verhandlungen des Reichstages des Norddeutschen Bundes, I. Legislatur-Periode, Session 1870 [Stenographic protocols of the proceedings of the Reichstag of the North German Confederation, $1^{\text {st }}$ parliamentary term, session 1870], vol. 4, document no. 158 , pp. $645,649-650$.

${ }^{21}$ Ibid. 650. These reasons were similar to those advanced by policy makers in other jurisdictions transitioning to incorporation by registration. See, for example, the speech by Robert Lowe, one of the main authors of company law reform in the mid- $19^{\text {th }}$ century, Hansard, $3^{\text {rd }}$ Series, vol. 140 (1856), pp. 116-138. Lowe pointed out that the 1844 Act (and the Limited Liability Act 1855, 18 \& 19 Vict., c. 133), 'so far from having been a means of preventing fraud, have only afforded facilities for its commission, because fraudulent persons have availed themselves of the sort of prestige which is gained among ignorant people by a presumed association with the Government, and have announced companies as "provisionally registered," and have thus given them a colour of respectability which their own merits would not obtain. It therefore appears to me that when the Government attempt, by a system of artificial restraints, to test the worth of any commercial undertaking, they endeavour to do what they are not able to accomplish.' Ibid. 123. Instead, according to Lowe, any legislation should be based on the principles of freedom of incorporation and caveat emptor: 'I am arguing in favour of human liberty - that people may be permitted to deal how and with whom they choose, without the officious interference of the State ... [I]n my judgment, the principle we should adopt is this, - not to throw the slightest obstacle in the way of limited companies being formed - because the effect of that would be to arrest ninety-nine good schemes in order that the bad hundredth might be prevented; but to allow them all to come into existence, and when difficulties arise to arm the courts of justice with 
aspect of disclosure, the periodic publication of the company's books and accounts, and not transaction-specific disclosure triggered by accessing public capital markets. Even the former type of disclosure was not fashioned in a particularly stringent manner. The management board was required to draw up a balance sheet, which had to be presented to the shareholders and published in the official gazette. ${ }^{22}$ The act also contained some relatively basic provisions on the form of the accounts ${ }^{23}$ and criminal sanctions in case the directors misrepresented the financial position of the company, ${ }^{24}$ but prospectus disclosure was not mentioned.

After the reforms of 1870 , the number of incorporations increased dramatically. In the decades before 1870, joint stock corporations numbered not more than a few hundred in the most industrialized states of Germany, with railways attracting most of the financing, ${ }^{25}$ whereas in the years 1870 (after the reforms entered into force in June) to 1874 alone, 857 companies were incorporated nationwide and railways were quickly replaced by industrial corporations as the most important issuers of equity. ${ }^{26}$

The laissez-faire regulation, arguably, contributed to the first major stock exchange crash in German history, the so-called 'founders' crash' (Gründerkrach) in $1873 .{ }^{27}$ In the years before the crash, issuers had succeeded in placing securities with only minimal information about the

sufficient powers to check extravagance or roguery in the management of companies, and to save them from the wreck in which they may be involved. That is the only way in which the Legislature should interfere, with the single exception — a very essential one — of giving the greatest publicity to the affairs of such companies, that everyone may know on what grounds he is dealing.' Ibid. 131. The German policy makers were well aware of the legal developments in the UK (and also in France and Italy) and did indeed refer to them to justify the German reforms, see for example Stenographic protocols, n 20 above, 651-652.

${ }^{22}$ Act of 1870, art. 239.

${ }^{23}$ Ibid. art. 239a.

${ }^{24}$ Ibid. art. 249.

${ }^{25}$ For Prussia, see for example Jakob Riesser, Die deutschen Großbanken und ihre Konzentration im Zusammenhang mit der Entwicklung der Gesamtwirtschaft in Deutschland (4 ${ }^{\text {th }}$ ed., G. Fischer 1912), 35, 43 (counting 102 stock corporations with an aggregate capital of c. 638 million marks that were founded from 1826-1850 and 295 stock corporations with an aggregate capital of c. 2,405 million marks from 1851-1870; of the invested capital, $72 \%$ was raised by railways); Alfred Reckendrees, 'Zur Funktion der Aktiengesellschaft in der frühen Industrialisierung' (2012) 53 Jahrbuch für Wirtschaftsgeschichte 137, 147-153 (analysing incorporations in Prussia in the period 1770-1869); Horst Thieme, 'Statistische Materialien zur Konzessionierung von Aktiengesellschaften in Preussen' (1960) 1 Jahrbuch für Wirtschaftsgeschichte 285, 286 (showing that the annual number of incorporations, not including railways and turnpikes, ranged between 1 and 31 during the period 17701867). For data on the capital of companies incorporated from 1800-1850, distinguishing between banks and trading companies, insurance undertakings, railways, other transportation companies, mining companies, and industrial corporations, see also Kurt Bösselmann, Die Entwicklung des deutschen Aktienwesens im 19. Jahrhundert (De Gruyter 1939), 199-200.

${ }^{26}$ The companies had an aggregate capital of c. 3.31 billion marks, see Riesser, n 25 above, 105-106.

${ }^{27}$ A vivid account of the founders' crash is given by Albert Schäffle, "Der "grosse Börsenkrach" des Jahres 1873' (1874) 30 Zeitschrift für die gesamte Staatswissenschaft 1. 
business, often simply by publishing an announcement in a newspaper and greatly exaggerating the prospects of the business. ${ }^{28}$ The atmosphere was characterised by a veritable speculative frenzy, which was fuelled by underwriters manipulating stock prices or presenting offerings incorrectly as oversubscribed in order to place the securities they had underwritten more easily. ${ }^{29}$ When exogenous shocks ${ }^{30}$ disturbed the confidence of investors, it became clear that the stock market rally was not sustainable. Investors realised that many companies had been incorporated merely with a view to raising funds for the promoters, without having a viable business model. The resulting crash triggered the insolvency of a large number of financial institutions and listed companies; the market capitalisation of German stock corporations decreased by about $46 \%$ and the real economy suffered considerably. ${ }^{31}$

The crash elicited a (somewhat belated) regulatory response in the form of a major overhaul of corporate law in $1884 .{ }^{32}$ However, this reform did not focus on strengthening the existing disclosure regime, but rather on tightening the rules on the formation of joint stock companies, which will be discussed below. ${ }^{33}$ To some extent, the lacuna in disclosure regulation was filled by the rules and regulations of the stock exchanges adopted since the 1880s, which required the publication of a prospectus before securities could be admitted to trading. The regulations specified in detail the content of the prospectus by providing for different regimes depending on the type of issuer and security ${ }^{34}$ For example, for shares of domestic industrial corporations, the prospectus had to contain information about the articles of association, objects, domicile and duration of the company, legal capital and amount of shares to be issued, rights attached to the shares, including pre-emptive rights and dividend rights, contributions in kind and payments made or other benefits granted in relation to the formation of the company, applicable accounting principles and principles on dividend

\footnotetext{
${ }^{28}$ Rainer Gömmel, 'Entstehung und Entwicklung der Effektenbörsen im 19. Jahrhundert bis 1914' in Hans Pohl (ed.), Deutsche Börsengeschichte (Fritz Knapp 1992), 153-155.

${ }^{29}$ Reichsoberhandelsgericht, Gutachten über die geeignetsten Mittel zur Abhülfe der nach den Erfahrungen des Reichs-Oberhandelsgerichts bei der Gründung, der Verwaltung und dem geschäftlichen Betriebe von Aktienunternehmungen hervorgetretenen Uebelstände, 31 March 1877, pp. 3-6, reprinted in Werner Schubert and Peter Hommelhoff (eds.), Hundert Jahre modernes Aktienrecht: eine Sammlung von Texten und Quellen zur Aktienrechtsreform 1884 mit zwei Einführungen (De Gruyter, 1985), 157.

${ }^{30}$ Political events in Paris, see Schäffle, n 27 above, 52.

${ }^{31}$ Gömmel, n 28 above, 155-157.

${ }^{32}$ Gesetz, betreffend die Kommanditgesellschaften auf Aktien und die Aktiengesellschaften [Act Concerning Limited Partnerships by Shares and Joint Stock Corporations], RGB1. 1884, p. 123, amending the General German Commercial Code.

${ }^{33}$ Text to notes $160-174$ below.

${ }^{34}$ See, for example, the regulations of the Berlin Stock Exchange of 1884, reproduced in Bericht der Börsen-Enquete-Kommission [Report of the Stock Exchange Commission of Inquiry] (1893), 47-51.
} 
distribution, and the names of the members of the management and supervisory boards. In addition, the company's articles and the last annual report had to be appended to the application. ${ }^{35}$ This regulatory framework remained largely unaltered until the end of the period here under investigation. ${ }^{36}$

\section{United Kingdom}

In the UK, disclosure became a central element of company law when the Joint Stock Companies Act of $1844{ }^{37}$ replaced the concession system with a liberal system of incorporation by registration. The 1844 Act, informed by the conviction of its primary author, William Gladstone, that publicity was 'the most effectual remedy' in that it brought 'the power of public opinion to bear on the proceedings of joint-stock companies, ${ }^{38}$ required for incorporation only the filing of a list of particulars with the registrar of companies that included information on the name, purpose, and principal place of business of the company, its promoters, officers, and subscribers, and a copy of every prospectus or other statement addressed to the public with a view to issuing and allotting the company's shares. ${ }^{39}$ The latter requirement is noteworthy for its wide scope, applying to any 'prospectus or circular, handbill or advertisement, or other such document at any time addressed to the public, or to the subscribers or others, relative to the formation or modification of [the] company'. ${ }^{40}$ Thus, the legislator intended to establish control over any form of communication with the public that could potentially influence the investors' decision to subscribe for securities. This stands in contrast to the approach in many other countries, where the obligation to disclose and file a prospectus is only triggered if an 'offer' is made to the public, defined as a communication that already contains relatively concrete information about the securities and the terms of the

\footnotetext{
${ }^{35}$ Report of the Stock Exchange Commission of Inquiry, ibid. 51.

${ }^{36}$ Importantly, the adoption of the Stock Exchange Act, n 14 above, did not extend disclosure obligations significantly. The Stock Exchange Act codified prospectus disclosure as a binding legal requirement (s. 38) and established liability for incorrect statements in the prospectus (ss. 43-44), but left the disclosure regime otherwise in place.

377 \& 8 Vict., c. 110. See $n 21$ above.

${ }^{38}$ The Economist, April 6, 1844, p. 655. See also Gladstone's statement in the House of Commons, Hansard, $3^{\text {rd }}$ Series, vol. 73 (1844), p. 1755. He was acutely aware of the importance of corporations for the economic development of the country and explained that the proposed Joint Stock Companies Act was intended to protect the public without unduly inhibiting honest business activity. The Act would, accordingly, not 'impose burthens and restraints upon [joint stock companies] other than such as were necessary or were manifestly to the public benefit.' The least intrusive measure was seen in 'giving a power of public opinion, and creating that responsibility which attached to all acts done in a public character.'

${ }^{39}$ Joint Stock Companies Act 1844, s. 4.

${ }^{40}$ Ibid. s. 4 , no. 8.
} 
offering, ${ }^{41}$ or, as initially in Germany, where the issuer seeks to obtain a stock exchange listing. On the other hand, the 1844 Act fell short of the standards set by most modern disclosure regimes in that it did not specify a particular content of the prospectus.

The disclosure obligations upon the formation of companies were supplemented by detailed, mandatory rules on the drawing-up, auditing, and disclosure of the company's financial accounts. ${ }^{42}$ The directors were responsible for producing periodical accounts and balance sheets, which had to be audited by external auditors appointed by the annual general meeting. Printed copies of the balance sheet and auditors report were sent to all shareholders before the ordinary general meeting, read at the meeting, and filed with the registrar of companies.

Only a few years later, the ambitious disclosure regime of the 1844 Act, however, started to be hollowed out. The first step towards a liberal regime characterised by light-touch regulation and limited intervention in the workings of companies came with the Joint Stock Companies Act 1847, which repealed the registration requirement for prospectuses because it was 'found to be very burdensome to the Promoters' ${ }^{43}$ The only remaining restriction on the use of prospectuses was the prohibition to publish any prospectus or other document addressed to the public containing information that had to be filed with the registrar of companies before the required particulars were so filed, or statements that were at variance with the particulars previously filed. ${ }^{44}$ Then, in 1856 , an act consolidating the various amendments to the Companies Act 1844 moved the rules on audited accounts into an appendix to the act laying down model articles that could be disapplied by the incorporators. ${ }^{45}$ The 1856 Act introduced a number of other changes facilitating the formation of companies, allowed registration with the most basic information to be filed, ${ }^{46}$ and did not undertake to regulate primary market disclosure in any way.

The amendments of 1847 and the Joint Stock Companies Act 1856 were said to have been adopted 'in the heyday of laissez-faire ${ }^{47}$ While the Act of 1856 constituted the pinnacle of the deregulatory movement and subsequent amendments began to make careful alterations to the free market system, the main contours of the disclosure framework established by the two

\footnotetext{
${ }^{41}$ See the definition of 'offer to the public' in the EU Prospectus Directive, Directive 2003/71/EC of the European Parliament and of the Council of 4 November 2003 on the prospectus to be published when securities are offered to the public or admitted to trading, [2003] OJ L 345, p. 64, art. 2(1)(d).

${ }^{42}$ Joint Stock Companies Act 1844, ss. 34-43.

${ }^{43}$ Joint Stock Companies Act 1847, 10 \& 11 Vict., c. 78, s. 4.

${ }^{44}$ Ibid. s. 7.

${ }^{45}$ Joint Stock Companies Act 1856, 19 \& 20 Vict., c. 47, s. 9 and Table B.

${ }^{46}$ Ibid. ss. 5, 12.

${ }^{47}$ Laurence C.B. Gower, The Principles of Modern Company Law (3 ${ }^{\text {rd }}$ ed., Stevens 1969), 49.
} 
Companies Acts remained in place until $1900 .^{48}$ The only noteworthy amendment during this period was brought about by the Companies Act 1867, which reintroduced the term 'prospectus' and required that prospectuses had to set out the dates and names of all contracts entered into by the company, promoters, and directors before the issue of the prospectus. ${ }^{49}$ However, the requirement to disclose contracts remained largely ineffective in practice because it could be evaded by including a so-called 'waiver clause' in the prospectus or in the form of application for shares. ${ }^{50}$

The disclosure regime was somewhat strengthened by the rules and regulations of the London Stock Exchange. ${ }^{51}$ The quotation of companies in the official list required, inter alia, that a prospectus was published that was in agreement with the articles of association, and that both the prospectus and the articles were filed with the stock exchange. ${ }^{52}$ However, the stock exchange rules did not seek to provide for a comprehensive disclosure regime supplanting the Companies Act and filling the void left by the legislator. Rather, they operated within the ambit of the existing legislative framework and selectively amplified certain requirements in response to abusive practices that had appeared in the markets. Recurring problems during times of booms in company formations were the gross overvaluation of assets acquired by the company, and consequently the lack of any relation between the market value of the assets and the company's valuation, and the allotment of a large proportion of the company's shares to the promoters or their nominees, who disposed of them at a premium in the secondary market without having made any payments on the shares. ${ }^{53}$ The stock exchange regulations sought to address these problems by requiring that a meaningful fraction of the capital issued

\footnotetext{
${ }^{48}$ The requirement to publish audited accounts was reinstated in the Companies Act $1879,42 \& 43$ Vict., c. 76, s. 7, for banking corporations.

${ }^{49}$ Companies Act 1867,30 \& 31 Vict., c. 131, s. 38.

${ }^{50}$ (1888) Economist 177-178. With time, the courts saw waiver clauses increasingly critically, see for example Greenwood v Leather Shod Wheel Company [1900] 1 Ch. 421.

${ }^{51}$ Contemporary discussions of the rules and regulations of the London Stock Exchange include Bertram O. Bircham and Frederick G.C. Morris, Public companies: a treatise on the law and practice relating to the formation and flotation of such joint companies limited by shares as invite the public to subscribe for their capital (E. Wilson 1911); B.E. Spencer Brodhurst, The Law and Practice of the Stock Exchange (W. Clowes 1897); Rudolph E. Melsheimer and Walter Laurence, The Law and Customs of the London Stock Exchange (H. Sweet 1879; further editions 1884, 1891, and 1905); Frederick J. Varley, Rules \& Regulations of the Stock Exchange. With notes and references to decided cases (E. Wilson 1925). For more recent studies see Larry Neal and Lance Davis, 'The evolution of the rules and regulations of the first emerging markets: the London, New York and Paris stock exchanges, 1792-1914' (2005) 45 Quarterly Review of Economics and Finance 296; Larry Neal, Lance Davis, and Eugene N. White, 'How it all began: The rise of listing requirements on the London, Berlin, Paris, and New York Stock Exchanges' (2003) 38 International Journal of Accounting 117.

${ }^{52}$ Mihill Slaughter, Rules and Regulations for the Conduct of Business on the Stock Exchange (London Stock Exchange 1873), Rules 128-129.

53 (1866) Economist 35-36; (1884) Economist 350-353; (1888) Economist 177-178. For a modern description of these practices see Cottrell, n 8 above, 266-267.
} 
was actually allotted and paid up, the contracts with the promoters were disclosed, and the articles of association contained certain further mechanisms designed to protect investors. ${ }^{54}$ However, enforcing these requirements was difficult, and the regulations did not succeed in eliminating the grievances that concerned the public. ${ }^{55}$

The binding legal regime was finally reformed by the Companies Act $1900,{ }^{56}$ which adopted four amendments significantly affecting disclosure regulation. First, it re-established the registration requirement for prospectuses that had been abolished in $1847 .{ }^{57}$ Second, it defined prospectuses widely, but arguably not as widely as the 1844 Act, so as to capture any statement offering securities to the public. ${ }^{58}$ Third, it required more comprehensive disclosures in the prospectus, including the number and amount of shares issued for a consideration other than in cash and the consideration for which they were issued, incorporation expenses, underwriting commissions, material contracts, and related party transactions, defined as any interest of a director in property to be acquired by the company and compensation for services rendered in connection with the formation of the company. ${ }^{59}$ Fourth, the provisions on external audits of the balance sheet were again made binding for all companies. ${ }^{60}$

In conclusion, in both the UK and Germany, the disclosure regime was fragmentary during most of the $19^{\text {th }}$ century. The duty to draw up and publish a balance sheet was introduced in

\footnotetext{
${ }^{54}$ Slaughter, n 52 above, Rules 128-129. The requirements for the quotation of shares were later renumbered as Rule 136, without being altered substantively until 1899 , when major revisions were adopted, see Brodhurst, n 51 above, 283-284. Rule 136, in the version of 1897, stipulated that an application for quotation of a company in the official list had to be accompanied by: 'The prospectus, ... the original application for shares, the allotment book, signed by the chairman and secretary to the company, and a certificate verified by the statutory declaration of the chairman and the secretary, stating the number of shares applied for and unconditionally allotted to the public, the amount of deposits paid thereon, and that such deposits are absolutely free from any lien, the bankers' pass-book and a certificate from the bankers stating the amount of deposits received.' Further, Rule 136 required 'that the prospectus shall have been publicly advertised, and that it agrees substantially with ... the articles of association ... that it provides for the issue of not less than one-half of the nominal capital, and for the payment of ten per cent. upon the amount subscribed, and sets forth the arrangements for raising the capital, whether by shares fully or partly paid-up, with the amounts of each respectively, and also states the amount paid, or to be paid, in money or otherwise to concessionaires, owners of property, or others on the formation of the company, or to contractors for works to be executed, and the number of shares, if any, proposed to be conditionally allotted; that two-thirds of the whole nominal capital proposed to be issued has been applied for and unconditionally allotted to the public (shares reserved or granted in lieu of money payments to concessionaires, owners of property, or others, not being counted to form part of such public allotment) ...'

${ }^{55}$ See the references in $\mathrm{n} 53$ above.

${ }^{56} 63$ \& 64 Vict., c. 48.

${ }^{57}$ Companies Act 1900, s. 9(3).

${ }^{58}$ Ibid. s. 30.

${ }^{59}$ Ibid. s. 10.

${ }^{60}$ Ibid. ss. 21-23.
} 
the two countries together with the general incorporation statutes in 1844 and 1870, respectively. However, with a brief interval in the UK from 1844 to 1856 , it was not supplemented by the requirement that the balance sheet had to be audited by external auditors. Some rules on prospectus disclosure can be found in the British company legislation as early as 1844, and the Companies Act 1867 contained a provision requiring the disclosure of preincorporation contracts in the prospectus, but it is difficult to speak of a binding, comprehensive disclosure regime before the amendments of 1900. In Germany, prospectus disclosure was not addressed by the legislator until the adoption of the Stock Exchange Act of 1896. The regulations of the stock exchanges, which were fairly detailed, filled the regulatory gap at least partly from the 1880s onwards. Thus, it can be said that with a time lag of about 20 years, Germany introduced similar provisions to those in the UK, either in statutory law or through stock exchange regulations. The main difference was, and it is an important one, that the German prospectus requirement was linked to the application for admission to trading on a stock exchange, since it was imposed by the regulations of the stock exchanges and later the Stock Exchange Act, and not by general company legislation. ${ }^{61}$ The prospectus regime under the UK Companies Act 1900, on the other hand, applied to any communication to the public that was intended to attract subscriptions for securities. However, this difference emerged relatively late, in 1900, when the British capital markets were already well developed.

\section{SHIFTING PARADIGMS: LIABILITY FOR INCORRECT DISCLOSURES}

\section{Germany}

In Germany, the liability of issuers and underwriters for incorrect market disclosures had been a controversial policy issue since the first joint stock corporations, mainly railways, started to offer securities to the public in greater numbers in the 1840s and 1850s. Until 1850, 28 railways were incorporated in Prussia, more than any other type of company. ${ }^{62}$ They were financed through the issue of shares and debentures, and their securities quickly became the object of speculation. ${ }^{63}$ Three reasons of a legal nature explain the predominance of railway securities during the early decades of German capital markets and their attractiveness as a speculative investment. First, it was permitted to subscribe to the shares before authorisation

\footnotetext{
${ }^{61}$ German Stock Exchange Act 1896, s. 38.

${ }^{62}$ Figures are provided by Bösselmann, n 25 above, 201.

63 Klaus J Hopt, 'Ideelle und wirtschaftiche Grundlagen der Aktien-, Bank- und Börsenrechtsentwicklung im 19. Jahrhundert' in Helmut Coing and Walter Wilhelm (eds.), Wissenschaft und Kodifikation des Privatrechts im 19. Jahrhundert (Vittorio Klostermann 1980), 128, 158.
} 
to incorporate had been granted. ${ }^{64}$ Second, in order to encourage the construction of further railway lines, the Prussian government guaranteed dividends and interest on railway securities and declared railway shares and debentures as suitable for the investment of money held in trust for wards. ${ }^{65}$ Third, as opposed to most other stock corporations, railways were able to issue bearer shares. ${ }^{66}$ These rules facilitated the raising of capital by railway corporations, but they also had the effect that a number of economically unviable companies were able to place their securities without great difficulties. ${ }^{67}$ The first attempt of the government to address this problem did not focus on improving disclosure and holding those liable who had made overly optimistic or incorrect statements, but on the increased use of concessions and prohibitions. A decree from 1844 provided that any offering of railway shares required authorisation by the minister of finance and time bargains in interim shares of railway corporations were prohibited. ${ }^{68}$ It has been observed that the undesired consequences of this decree were similar to the Bubble Act of $1720 .{ }^{69}$ Fearing that trading in railway securities would become all but impossible, many investors withdrew their capital, the stock market collapsed, and even reputable railway corporations faced problems in obtaining financing.

In the next decade, another financial scandal, again about a railway company, provided the necessary impetus for a more nuanced policy discussion, an in-depth academic treatment of liability for misstatements to the market, and court decisions that sought to adjust common law principles in order to develop doctrines suitable for capital-market-specific problems. ${ }^{70}$ The case, the so-called Lucca-Pistoia-Controversy, concerned an Italian railway corporation that had obtained a concession to construct a railway between Lucca and Pistoia in Tuscany.

\footnotetext{
${ }^{64}$ Ministerialblatt für die gesamte innere Verwaltung in den Königlich Preußischen Staaten [Ministerial Gazette of the entire interior administration of the Royal Prussian States] 1840, 420.

${ }^{65}$ Decree of 22 December 1843, Gesetz-Sammlung für die Königlich-Preußischen Staaten [Collection of Laws of the Royal Prussian States] 1844, p. 45.

${ }^{66}$ The issue of bearers shares needed to be explicitly authorised (s. 11 of the Prussian Stock Corporation Act of 1843), and a ministerial decree stipulated that such authorisation should be granted only if the company, according to its objects, served the common good, Ministerialblatt für die gesamte innere Verwaltung in den Königlich Preußischen Staaten 1845, 121.

${ }^{67}$ Bösselmann, n 25 above, 21-22.

${ }^{68}$ Decree of 24 May 1844, Gesetz-Sammlung für die Königlich-Preußischen Staaten 1844, p. 117.

${ }^{69}$ Hopt, n 63 above, 158-159.

${ }^{70}$ The main academic contributions are two books from Levin Goldschmidt, Der Lucca-Pistoja-ActienStreit (J.D. Sauerländer's Verlag 1859) [hereinafter Goldschmidt, 'Actien-Streit'] and Nachtrag zu den handelsrechtlichen Erörterungen über den Lucca-Pistoja-Actien-Streit (J.D. Sauerländer's Verlag 1861) [hereinafter Goldschmidt, 'Nachtrag']; as well as Rudolf von Jhering, Der Lucca-Pistoja Actienstreit: Ein Beitrag zu mehreren Fragen des Obligationsrechts, insbesondere der Theorie des dolus und der Lehre von der Stellvertretung (Zernin 1867). The most important court decisions are reproduced in Goldschmidt, 'Actien-Streit', Appendices XII-XVI. For a more recent summary of this case and the ensuing academic debate see Heinz-Dieter Assmann, Prospekthaftung (Carl Heymanns Verlag 1985), 47-51.
} 
The project was potentially highly profitable because the railway would connect two already existing lines. The company issued preference shares that were offered to the public in Germany by a Frankfurt-based banking institution in 1853. The bank published a prospectus that contained, among other information, the statement that annual 'interest payments' of 5\% on the preference shares were backed by a guarantee of the government of Tuscany (more correctly a guaranteed dividend), without however mentioning that the railway's concession, and hence also the guarantee, might be revoked if construction of the railway line was not completed within a specified period of time. In addition, the prospectus stated that 'in light of information scrupulously collected by the bank a return of considerably more than $10 \%$ could be expected' ${ }^{71}$ On the first day of the offering period, the issue was already three to four times oversubscribed and all shares were allotted. Because of events unrelated to the Frankfurt bank, in particular fraudulent acts of another underwriter and the 'incompetence' of the railway corporation's directors, the completion of the railway line was delayed considerably, with the consequence that the government guarantee was forfeited and the shares depreciated greatly in value. ${ }^{72}$

At the time of the controversy, different types of underwriting, comparable to best efforts and firm commitment underwriting, were already well developed. ${ }^{73}$ It was unclear in the case whether the Frankfurt bank was offering the securities as a seller in their own name or as an agent on behalf of the issuer, and the courts apparently interpreted the facts differently in this regard. ${ }^{74}$ If a contractual relationship did not exist between the investors and those responsible for the prospectus, investors had to rely mainly on the actio doli, which was somewhat comparable to the common law tort of deceit ${ }^{75}$ and required a showing of intent to defraud. ${ }^{76}$ Even in cases where the investors purchased directly from the issuer of the prospectus, common law principles made it difficult for them to recover, but some courts in the LuccaPistoia-proceedings interpreted traditional doctrines in a flexible way and held the Frankfurt bank liable, as will be discussed presently.

It is interesting to compare the different points of reference that the courts and commentators used to analyse the liability of the bank. Some adopted what might be called a traditional sales-focused perspective: they discussed whether the object of the investment - the shares of

\footnotetext{
${ }^{71}$ Goldschmidt, 'Actien-Streit', 1-2 (translation by author).

${ }^{72}$ Ibid. 5-10.

${ }^{73}$ Ibid. 13-14.

${ }^{74}$ Ibid. 18-19.

${ }^{75}$ For a comparison of the Roman actio doli and the tort of deceit see WW Buckland and Arnold D McNair, Roman Law and Common Law: A Comparison in Outline (2 ${ }^{\text {nd }}$ ed., CUP, 1952), 383-390.

${ }^{76}$ Friedrich Carl von Savigny, System des heutigen Römischen Rechts, vol. 3 (Veit 1840), 118.
} 
a railway corporation - were defective. Emphasising that the financial success of a railway line that was still under construction depended on various factors that might or might not be under the control of the railway corporation, and certainly not under the control of intermediaries, they argued that the seller of securities did not guarantee, and the buyer did not expect the seller to guarantee, that the investment would generate a specific return or the construction project would be completed within a specific timeframe. Thus, the expected return on investment mentioned in the offering prospectus of the Frankfurt bank, or the fact that the prospectus did not elaborate on the consequences of a delay in completing the construction of the railway for the government guarantee, did not give rise to claims by investors. 'Evidently', as one contemporary commentator pointed out, 'Mr Goldschmidt [the underwriter] did not want to promise an unconditional interest guarantee to subscribers' ${ }^{77}$ Similarly, 'all subscribers knew that they were purchasing shares of a railway still under construction and were, accordingly, running all the risks that the acquisition of such shares typically entails. ${ }^{, 78}$

The court of appeal in one of the ensuing proceedings seems to have been informed by this approach when it held that the statement of an expected return of more than $10 \%$ was mere 'sales promotion', which was not actionable unless the calculations were made without any factual basis. ${ }^{79}$ However, at the same time, the court deviated from the conventional line of reasoning and adopted a disclosure-focused perspective with regard to the omitted conditions of the government guarantee. In the context of a traditional claim arising out of contract, the actio empti, according to which the seller is liable if the goods do not have the promised characteristics or the seller fraudulently (with dolus) conceals a defect, ${ }^{80}$ the court developed elements of a cause of action that were essentially not concerned with the quality of the securities, but with the completeness of the information contained in the prospectus. In this sense, the court's analysis began to resemble modern prospectus liability claims. The court held that the cause of action required: first, an incorrect statement or omission; second, materiality of the misstatement or omission; and third that the defendant had knowingly concealed the true facts. ${ }^{81}$ The last condition resulted from the chosen cause of action, the actio empti. The claimant was therefore in a similar position to purchasers on the secondary market who could not bring a contractual claim against the issuer of the prospectus. If the

\footnotetext{
${ }^{77}$ Goldschmidt, ‘Actien-Streit', n 70 above, 40 (translation by author).

${ }^{78}$ Ibid. 41 (translation by author).

${ }^{79}$ Ober-Appellationsgericht der vier freien Städte zu Lübeck [Higher Court of Appeal of the four free cities at Lübeck], decision of 31 May 1858, reproduced ibid. XXXVII, at p. XLII.

${ }^{80}$ Von Savigny, n 76 above, 289.

${ }^{81}$ Ober-Appellationsgericht, reproduced in Goldschmidt, 'Actien-Streit', n 70 above, XLIII-XLIV.
} 
three conditions were satisfied, as was the case in the Lucca-Pistoia proceedings, ${ }^{82}$ the defendant bore the burden of proving that the claimant was aware of the misstatement at the time of the transaction. ${ }^{83}$

Thus, we find the law in the 1850 s at a transitory point. On the one hand, much of the legal analysis still used face-to-face transactions and the sale-of-goods paradigm as the relevant contextual framework. On the other hand, it was clear to the courts that the traditional legal principles were not calibrated well to address issues that arose when securities were offered to the public by means of a prospectus or a comparable publication inviting subscriptions. For this reason, the focus of the analysis shifted to the function performed by prospectuses: conditioning the market by conveying potentially selective information to the public. Of course, possible avenues of purchasers in the primary or secondary market to claim damages were still limited. Both types of investor generally had to show dolus, which implied that the issuer of the prospectus intended to deceive, and did deceive, the purchaser. The investor had to rely on the prospectus and had to be motivated by the misstatement or omission to enter into the transaction. In most cases, these requirements made it impossible for purchasers on the secondary market to bring a claim. In addition, they did not provide any incentive for those who drafted and published a prospectus to verify the information they had obtained about the issuer. The gatekeeper function of reputational intermediaries that is reinforced by the private enforcement machinery of modern securities regulation, therefore, was not utilized by these early attempts to formulate principles of prospectus liability. ${ }^{84}$ Nevertheless, the first steps towards a disclosure-focused conceptualisation of existing liability provisions were taken.

In the following decades, the legal development continued down the path taken in the LuccaPistoia-proceedings with incremental innovations. The amendments to the General German Commercial Code of 1884, which tightened the regulation of joint stock corporations in reaction to the perceived abuses of the freedom of incorporation after the abolishment of the concession system in 1870 , introduced two provisions establishing liability of those who

\footnotetext{
${ }^{82}$ The court of appeal was, however, criticised for interpreting the requirements of dolus too broadly, see ibid. 69, since it was at the time controversial what dolus in an actio empti involved. For an overview of the different opinions see Assmann, n 70 above, 49. Notwithstanding the legal disagreement, the point illustrates that the court was prepared to invoke traditional doctrines in a way that was not universally accepted in order to make them operational in the context of impersonal markets.

${ }^{83}$ Goldschmidt, 'Actien-Streit', n 70 above, XLV-XLVI.

${ }^{84}$ The most comprehensive treatment of the function of gatekeepers in securities regulation is probably John C Coffee Jr., Gatekeepers: The Professions and Corporate Governance (OUP 2006). The concept was pioneered by Reinier H Kraakman, 'Corporate Liability Strategies and the Costs of Legal Controls', 93 Yale L. J. 857 (1984); Reinier H Kraakman, 'Gatekeepers: The Anatomy of a Third-Party Enforcement Strategy', 2 J. L. Econ. \& Org. 53 (1986).
} 
made incorrect public statements in order to induce investors to subscribe for securities. ${ }^{85}$ However, both provisions remained largely ineffectual. The first imposed liability on anyone who knew or, employing the care of a conscientious manager, should have known that an announcement offering shares to the public was incorrect or incomplete, but liability existed only in relation to the company and only for misstatements made within two years after incorporation regarding the capital structure of the company or the valuation of contributions in kind. ${ }^{86}$ The scope of the second provision was broader, capturing any incorrect statement in public announcements made to attract investments and any deceptive device employed to affect the stock market price of the company's shares. ${ }^{87}$ However, since the provision was designed as a criminal offence, it sanctioned only intentional or fraudulent acts.

The courts took recourse to a different, much older legal concept to develop the contours of prospectus liability in cases where fraud could not be shown and the investor had not bought from the issuer of the prospectus. In a leading case ${ }^{88}$ that involved an incorrect prospectus published in several newspapers by a promoter of the issuer and chairman of its supervisory board, the Imperial Court relied on the rules on advice and recommendations from the General Prussian Common Law adopted in the $18^{\text {th }}$ century, ${ }^{89}$ which provided for three types of liability: anyone was responsible for the consequences of knowingly incorrect statements or knowingly detrimental recommendations; experts who gave advice within their field of expertise were additionally liable for gross negligence; and finally, if they received remuneration for their advice, liability existed for any form of negligence. ${ }^{90}$

The claimant in the case had bought shares from an intermediary in the primary market. He sought damages from the chairman of the supervisory board, arguing that he had relied on the prospectus in making the investment decision. The court qualified the offering prospectus as 'advice' and a 'recommendation', since the prospectus contained information relevant to the determination of the value of an investment opportunity. ${ }^{91}$ Interestingly, the court was also prepared to accept without further discussion that the rules on advice and recommendations

\footnotetext{
${ }^{85}$ Act of 1884, n 32 above, arts 213b, 249d.

${ }^{86}$ Art 213b. The provision was an expression of the focus of the 1884 amendments on the act of formation and legal capital as the main strategies to protect investors.

${ }^{87}$ Art 249d, nos. 1 and 2.

${ }^{88}$ Decision of 24 February 1897, RGZ 39, 245.

${ }^{89}$ Allgemeines Landrecht für die Preußischen Staaten of 1 June 1794 (ALR), reproduced in Hans Hattenhauer and Günther Bernert, Allgemeines Landrecht für die preußischen Staaten von 1794 (Luchterhand, 3rd ed. 1996).

${ }^{90}$ ALR, $\S \S 218-220$ I.13. For a discussion of the provision, see Karl Lehmann, Das Recht der Aktiengesellschaften, vol. 1 (Carl Heymanns, 1898), 475.

${ }^{91}$ RGZ 39, 245, 248.
} 
applied to statements made to an undefined, potentially unlimited class of persons, such as investors in a public offering. ${ }^{92}$ It is unclear whether these principles would apply to purchasers in the aftermarket, or the court would inquire into the purpose of the offering prospectus. ${ }^{93}$ However, the decision indicates that at least purchasers in the primary market who read the incorrect prospectus and relied on it were entitled to claim damages for the loss suffered as a consequence of the investment, provided that the misstatement was made intentionally or, if the defendant was an expert, for example a banking institution, grossly negligently. Thus, the holding significantly facilitated recovery by investors compared with the legal situation presented above. However, the characterisation of the offering prospectus as advice or a recommendation remained controversial in the literature, and the law was not settled until the legislator stepped in to reform prospectus liability in $1896 .{ }^{94}$

\section{United Kingdom}

The evolution of a private cause of action for misstatements in the prospectus or other communications addressed to potential investors under English law has been described as 'haphazard', with courts (and the legislature) reacting 'to economic changes in an ad hoc, unsystematic way. ${ }^{95}$ The need to determine the responsibility of promoters and directors for misrepresentations arose with the boom in company formations starting in the early $19^{\text {th }}$ century. The years before the repeal of the Bubble Act in $1825^{96}$ saw a surge in company promotions and widespread speculation in shares. ${ }^{97}$ The boom ended abruptly in the second half of 1825 with a stock market crash, bank runs and a credit crunch that led to the failure of $80 \%$ of the companies formed during the boom. ${ }^{98}$ Macroeconomic factors were most likely

\footnotetext{
${ }^{92}$ Ibid. The only controversially discussed issue was whether the defendant, being an expert within the meaning of the law, should be liable for any form of negligence or only for gross negligence.

${ }^{93}$ A similar question has arisen under English law, where at least one court has held that the purpose of the prospectus is determinative, Possfund Custodian Trustees v Diamond [1996] 1 W.L.R. 1351, 13611366.

${ }^{94}$ For the 1896 reforms, see the references in notes 140-141 below.

${ }^{95}$ Michael Lobban, 'Nineteenth Century Frauds in Company Formation: Derry v Peek in Context' (1996) 112 LQR 287, 288, 317.

${ }^{96}$ An Act to repeal so much of an Act passed in the Sixth Year of His late Majesty King George the First, as relates to the restraining several extravagant and unwarrantable Practices in the said Act mentioned; and for conferring additional Powers upon His Majesty, with respect to the granting of Charters of Incorporation to trading and other Companies, 1825, 6 Geo. 4, c. 91.

${ }^{97}$ In 1824 and 1825, 624 joint stock companies were formed with a nominal capital of $£ 372 \mathrm{~m}$, Arthur D. Gayer, Anna J. Schwartz, and Walt W. Rostow, The Growth and Fluctuation of the British Economy, 1790-1850, Vol. I (Clarendon Press, 1953) 412.

${ }^{98}$ Larry Neal, 'The Financial Crisis of 1825 and the Restructuring of the British Financial System' (1998) 80 Review - Federal Reserve Bank of St. Louis 53, 64-65.
} 
the main contributing cause of the crisis. ${ }^{99}$ However, part of the blame falls on investors who were gripped by a speculative frenzy and invested in questionable ventures floated with minimal information ${ }^{100}$ and only a fraction of the legal capital paid up. ${ }^{101}$ It is, therefore, unsurprising that public opinion and the courts were initially not sympathetic to those who had lost their investment in the crash. ${ }^{102}$ The difficulties faced by investors were compounded by the fact that companies founded without royal charter were qualified as partnerships. An investor who had bought shares on the basis of a misleading prospectus and become a partner ${ }^{103}$ could not sue his fellow partners at common law, because that was seen as being tantamount to suing himself. ${ }^{104}$ Equity allowed the investor to petition the court to dissolve the partnership and take an account, but the courts were adamant that all partners had to be made parties to the suit, even if they numbered in the hundreds. ${ }^{105}$

However, over the next decades, as company promotions became a more common phenomenon, the courts began to open up avenues to grant investors remedies at law and in equity if they subscribed for shares in a projected company that was presented as a wellcapitalised undertaking, but that was abandoned without having been incorporated by statute and without ever having operated. ${ }^{106}$ It is instructive to examine the approach of the courts in dealing with such cases. The common law courts, similar to the courts in Germany, assessed the subscription for shares primarily through the lens of a contract for the purchase of something with particular characteristics. They asked whether the investor had received what he had asked for: 'shares in a practicable scheme', i.e. in a concern with sufficient capital, to be raised by the issue of a specified number of shares. ${ }^{107}$ If that was not the case, if the

\footnotetext{
${ }^{99}$ Notably, expansionary monetary policy by the Bank of England in the years before the crisis fuelled the boom, and the tightening of monetary policy in the beginning of 1825 was a catalyst for the crash, Michael D. Bordo, 'Commentary on "The Financial Crisis of 1825 and the Restructuring of the British Financial System”” (1998) 80 Review - Federal Reserve Bank of St. Louis 77, 79.

${ }^{100}$ Neal, n 98 above, 64, 75.

${ }^{101}$ The figures reported in Gayer, Schwartz, and Rostow, n 97 above, 412-414, show that only 4.27\% of the legal capital of the companies formed in 1824-1825 and later abandoned was paid up. Even in newly formed companies that survived the crash (127 of 624 company promotions), the paid up capital amounted only to $14.78 \%$.

${ }^{102}$ See Lobban, n 95 above, 289-290, for references.

${ }^{103}$ The courts did not qualify all subscribers for shares as partners; in particular, they were prepared to allow investors to recover the money paid for shares in an action for money had and received if the undertaking was abandoned without ever operating, see Kempson v Saunders (1826) 4 Bing. 5.

${ }^{104}$ For a discussion of this point see Seddon v Connell (1840) 10 Sim. 58.

${ }^{105}$ This was the case in Van Sandau v Moore (1826) 1 Russ. 441.

${ }^{106}$ For a description of common problems that arose in the context of company formations, see text to $\mathrm{n}$ 53 above.

${ }^{107}$ Wontner v Shairp (1847) 4 C.B. 404, 441.
} 
investor had instead 'received shares in a scheme that was impracticable, and which was rendered so by the act of the [defendants] in refusing to allot more than [a fraction of the specified number of] shares, ${ }^{108}$ there was a 'failure of consideration': 'That which was allotted not being in truth that which the plaintiff had asked for, he was not bound to take it. ${ }^{109}$

Thus, the starting point of the courts' analysis was not the act of disclosing incorrect information, but the variance between the promised and the actual characteristics of the projected undertaking and hence, by extension, of the acquired securities. The courts did not yet appreciate that disclosure played a different role in impersonal markets than in face-toface transactions and that it might be necessary, therefore, to develop distinct regulatory concepts regarding the former. It has been pointed out that the courts were not guided by general principles informed, for example, by the goal of investor protection or the efficiency of price formation. Rather, that 'the question of liability for failed enterprise depended on a number of factors to be seen case by case-whether there had been fraud, what contract the allottee had signed, how much authority directors were given., ${ }^{110}$

Variance between the promised and the actual characteristics of the scheme did not end the inquiry if the investor had entered into a binding subscription agreement authorising the directors to use the deposits for expenses incurred in the formation of the business. An action for money had and received would fail unless the plaintiff was able to show that the misrepresentation was fraudulent and that it had been a material inducement to the investor to subscribe for the shares. ${ }^{111}$ This was by no means impossible in cases where the projected company had to be abandoned because it was undercapitalised and the directors had sought to enrich themselves through the allotment of shares to themselves. However, where the company had been set up as a viable undertaking and had operated for some time, this approach made it difficult to hold the managers accountable for misstatements, for example overly optimistic financial reports. The investors could take recourse to an action for deceit, but it was generally agreed that in order to sustain such an action they had to prove that the defendants made representations to the investors ${ }^{112}$ that were materially false, they knew that

\footnotetext{
108 Ibid.

${ }^{109}$ Ibid. The cause of action to recover the deposit was for 'money had and received'. See also Walstab v Spottiswoode (1846) 15 M. \& W. 501; Nockells v Crosby (1825) 3 B. \& C. 814.

${ }^{110}$ Lobban, n 95 above, 303.

111 Jarrett $v$ Kennedy (1848) 6 C.B. 319.

${ }^{112}$ It was not necessary that the misrepresentations were made directly to the investors, provided that they were contained in a prospectus that was circulated among a class of persons to which the investor belonged, Clarke v Dickson (1859) 6 C.B. N.S. 453.
} 
the statements were not true (or did not believe in their truth), intended the plaintiffs to act on them, and the plaintiffs did act on the misstatement. ${ }^{113}$

In equity, the courts came to the same conclusion. If the plaintiffs were entitled to relief at law in an action for money had and received because of fraudulent misstatements ${ }^{114}$ or because they had invested in a 'bubble company', a scheme that was abandoned before it was fully incorporated, courts of equity held that the investors could recover their deposits from those who had published the misleading prospectus or made the misrepresentations. ${ }^{115}$

Courts started to make careful alterations to the above concepts that were more accommodating to investors who had bought shares in reliance on a misleading prospectus during the second half of the century. The notion of the company as an entity clearly distinct from its shareholders became embedded in legal reasoning with the reforms introduced by the Limited Liability Act $1855^{116}$ and the Joint Stock Companies Act $1856,{ }^{117}$ which simplified the process of registration and replaced the deed of settlement with the memorandum and articles of association. At the same time, it became more common for the middle class to invest in the capital markets. The economy was increasingly characterised by the paradigm of the passive investor who took shares in a professionally managed company. ${ }^{118}$ Therefore, it was less natural to draw an analogy with the business form of the partnership and assume that third parties traded with the company on the faith that those who were held out as shareholders indeed possessed that quality. ${ }^{119}$

As a consequence, we now find decisions that allowed rescission of the share purchase agreement in cases falling short of a fraudulent misrepresentation. In 1869, in the wake of another boom in company formations and another stock market crash, the House of Lords held in a landmark decisions that investors were entitled to rescind if they had been induced

\footnotetext{
${ }^{113}$ Taylor v Ashton (1843) 11 M. \& W. 401; Bale v Cleland (1864) 4 F. \& F. 117.

${ }^{114}$ For example, lain v Agar (1828) 2 Sim. 289; Stainbank v Fernley (1839) 9 Sim. 556.

${ }^{115}$ Green v Barrett (1826) 1 Sim. 45, relying on Colt v Woollaston (1723) 2 P. Wms. 154, and holding directors liable because 'the prospectus ... was published, not with any intention to establish a company upon the principles there stated, but as a snare to persons who might unwarily become subscribers, and for the purpose of enabling the directors to make a profit by the sale of shares which they thought fit to assume to themselves', ibid. 51.

11618 \& 19 Vict., c. 133.

$11719 \& 20$ Vict., c. 47.

${ }^{118}$ Cottrell, n 8 above, 278-279. Comprehensive data on the social composition of investors in joint stock companies for the years 1860 and 1885 has been compiled by Philip L Cottrell, Industrial Finance 1830-1914 (Methuen 1980), 95-97.

${ }^{119}$ This argument had still been made, for example, in Henderson v Royal British Bank (1857) 7 El. \& B1. 356.
} 
to purchase the shares on the misrepresentation of a material fact, ${ }^{120}$ even if the directors had not been aware of the untruth of the statements and had not acted fraudulently. ${ }^{121}$ It is possible to discern a change in the courts' reasoning at this juncture. The courts recognised that the prospectus functioned as an instrument that alleviated the informational disadvantage of investors. They emphasised that 'the shareholders had not the means afforded to them of forming an independent judgment on [the] subject [of the likely return on their investment]. ${ }^{122}$ A first corollary of the recognition of the informational function of prospectuses was the imposition of more stringent duties on directors. Investors were entitled to assume that the directors, 'as men of character and honour, knew to be true that which [they] stated', ${ }^{123}$ and the law accordingly held them responsible if they made misstatements in prospectuses in ignorance of their truth or untruth. A second corollary was the acknowledgement that misrepresentations did not affect the purchased shares themselves. They did not constitute a defect of the shares that diminished their value in the hands of the initial allottee as well as buyers in the secondary market. ${ }^{124}$ Rather, the question was whether the buyer was a member of the circle of persons whom the misrepresentation was intended to influence or, to put it differently, whether the communication was directed at the market in which the buyer was operating. ${ }^{125}$

${ }^{120}$ Reese River Silver Mining Company v Smith (1869-70) L.R. 4 H.L. 64. The law developed quickly in the 1860s. Courts initially still required that the directors had made a fraudulent misrepresentation, but they now qualified directors as agents of the company and held that the directors' frauds were imputable to the company. See, e.g., New Brunswick Railway v Conybeare (1862) 9 H.L. Cas. 711; Western Bank of Scotland v Addie (1866-69) L.R. 1 Sc. 145.

${ }^{121}$ The requirements were more stringent in a direct action against the directors, although the law was also fluctuating on that point in the 1860s and 1870s, as will be discussed presently in the text.

${ }^{122}$ Peek v Gurney (1871-72) LR 13 Eq. 79, 115.

${ }^{123}$ Reese River Silver Mining Company v Smith (1869-70) L.R. 4 H.L. 64 at 72 per Lord Hatherley.

${ }^{124}$ Peek v Gurney (1871-72) LR 13 Eq. 79 at 117: '[A] question of considerable importance and of a distinct character arises as regards the transfer of a share, namely, whether the misconduct of the directors is a vice that taints the share itself, into whosesoever hands it passes, or whether the share itself is purified by the conduct of the allottee or any subsequent holder of the share.'

${ }^{125}$ This was one of the points on which the plaintiff in Peek $v$ Gurney lost. The plaintiff had obtained the misleading prospectus from someone (it was not proved from whom) at the time of the initial public offering, but he had no money to invest then. He kept the prospectus and, three months later, when his financial situation had improved, bought shares in the open market. Both the Court of Chancery and the House of Lords on appeal denied the plaintiff's action. The arguments in the two courts were somewhat different, but they amounted essentially to the same. Lord Romilly in the Court of Chancery held that the existence of a misrepresentation that induced the investor to buy shares had to be judged from the perspective of the original allottee: if the allottee did not rely on the misrepresentation or if he later condoned it, then the transferee was also barred from recovery, even if he had in fact bought on the faith of the prospectus. See Peek v Gurney (1871-72) LR 13 Eq. 79 at 117-118. The House of Lords argued that 'there must be something to connect the directors making the representation with the party complaining that he has been deceived and injured by it', (1873) L.R. 6 H.L. 377 at 399. In the case at hand, the court drew a distinction between communications made with a view to informing anyone who was disposed to deal in the company's securities (the court referred to Scott v Dixon 29 L. J. (Ex.) 
Thus, we can identify in Britain a paradigm shift similar to the one that occurred in Germany at about the same time. Courts relied less on legal concepts and arguments designed to regulated face-to-face transactions. Instead, they paid increasing attention to the role that information played in impersonal markets and recognised the need to reformulate and modify traditional regulatory concepts. Nevertheless, to hold that this conceptual shift protected investors comprehensively against misrepresentations would be an overstatement. Shareholders had a duty to use all reasonable diligence in ascertaining that the relevant representations were correct and, if found to be incorrect, exercise their right to rescind the contract within a reasonable time and certainly before the winding-up of the company commenced. ${ }^{126}$ In addition, even if a fraud had been committed that was imputable to the company, ${ }^{127}$ the courts generally denied the shareholders the right to sue the company itself for damages. ${ }^{128}$

In many cases, therefore, the only remedy available to investors was a direct action against the directors who had issued the misleading statement. In some decisions from the 1860s, the courts had made sweeping statements that seemed to anticipate a sea change in how misleading disclosures were regulated. While these statements stemmed from decisions dealing with actions for rescission, they implied that directors might be held accountable not only for fraudulent, but also for negligent misrepresentations. ${ }^{129}$

62, n. to the case of Bedford v Bagshaw, as an example), and invitations to the public to apply for allotments of shares on the occasion of the public offering. In the latter case, the communication was addressed to the original allottees and not to purchasers in the open market. Lord Colonsay made the point very clearly: 'I agree that the proper office of a prospectus is to invite persons to become original partners in a company, that is to say, allottees of shares; and I do not think that the responsibility towards those allottees which attached to the directors who issued the prospectus, followed the shares when they were transferred to any number of persons however distant from the allottees, persons who ultimately purchased those shares.' Ibid. 401.

${ }^{126}$ Oakes v Turquand (1867) L.R. 2 H.L. 325; Peek v Gurney (1871-72) LR 13 Eq. 79 at 118-120.

${ }^{127}$ This was held to be the case if the director committed the fraud in the course of business, Barwick $v$ English Joint Stock Bank (1866-67) L.R. 2 Ex. 259.

${ }^{128}$ Houldsworth v City of Glasgow Bank (1880) 5 App. Cas. 317 (dealing with an unlimited company incorporated under the Companies Act 1862).

${ }^{129}$ See, for example, the holding of the Court of Chancery in New Brunswick and Canada Railway Company v. Muggeridge, 1 Dr. \& Sm. 363 at 381-382: '[T] those who issue a prospectus holding out to the public the great advantages which will accrue to persons who will take shares in a proposed undertaking, and inviting them to take shares on the faith of the representations therein contained, are bound to state everything with strict and scrupulous accuracy, and not only to abstain from stating as fact that which is not so, but to omit no one fact within their knowledge the existence of which might in any degree affect the nature, or extent, or quality of the privileges and advantages which the prospectus holds out as inducements to take shares.' The holding was confirmed in Central Railway Company of Venezuela $v$ Kisch (1867) L.R. 2 H.L. 99. 
In Derry v Peek, ${ }^{130}$ the leading case on common law prospectus liability until Hedley Byrne $v$ Heller $^{131}$ introduced the tort of negligent misrepresentation, the Court of Appeal emulated this approach. ${ }^{132}$ The case concerned an undertaking incorporated to operate a tramway, whose offering prospectus stated that the company had obtained the permission to use steampowered carriages. The permission had in fact not yet been granted unconditionally, and when the Board of Trade refused the necessary consent, the company had to be wound up. At trial, evidence was given that the directors had been confident that consent would be given and that they had not acted with intent to defraud the investors. The question was, therefore, what degree of 'moral culpability' was required in an action of deceit: dishonesty, or whether it was sufficient that the defendant made a false statement carelessly but honestly. The Court of Appeal held that the latter was the case. A director or other person who 'makes statements which he desires that others should act upon ... [is subject to a duty] to take care that he has reasonable ground for the material statements which are contained in that document which he prepares and circulates'. ${ }^{133}$ If the statements are made without exercising the necessary care to ascertain that they are correct, the director 'is liable civilly as much as a person who commits what is usually called fraud, and tells an untruth knowing it to be an untruth. ${ }^{134}$ These were far-ranging pronouncements. The justices were, of course, well aware that the law on this point was not settled and that it was not easy to reconcile their interpretation with some of the applicable precedents. ${ }^{135}$ That they were willing to extend the notion of deceit to behaviour lacking dishonesty shows the unease that existed at the time about the legal mechanisms available to regulate public offerings and protect investors representing increasingly broad and varied sections of society. ${ }^{136}$

The House of Lords, however, was not prepared to take the same leap. It overruled the decision of the Court of Appeal and made it clear that the claimant in an action of deceit must prove actual fraud. Fraud was held to require a showing 'that a false representation has been made (1) knowingly, or (2) without belief in its truth, or (3) recklessly, careless whether it be

\footnotetext{
${ }^{130}$ (1887) 37 Ch. D. 541.

${ }^{131}$ [1964] AC 465.

${ }^{132}$ Similar statements can be found obiter in Smith v Chadwick (1882) 20 Ch. D. 27 at 44.

${ }^{133}$ (1887) 37 Ch. D. 541 at 567-568 per Cotton L.J.

${ }^{134}$ Ibid. 568.

${ }^{135}$ See Cotton L.J.'s discussion of Edgington v. Fitzmaurice (1885) 29 Ch. D. 459 and Hannen L.J.'s reliance on the case law on rescission, 37 Ch. D. 541 at 566-568 and 580-582. However, see also Lopes L.J., who remarked that '[t]he law I venture to say is well settled and well understood', ibid. 585.

${ }^{136}$ See, for example, the highly critical assessment by F. Pollock, 'Derry v. Peek in the House of Lords' (1889) 5 LQR 410.
} 
true or false. ${ }^{137}$ Thus, a statement, even if made without reasonable ground for believing it, will not necessarily give rise to liability, provided that it was 'made honestly, and in the full belief that it was true'. ${ }^{138}$ This decision, if read together with Peek $v$ Gurney, where it was held that offering prospectuses were only addressed to the original allottees, ${ }^{139}$ made it almost impossible for purchasers in the aftermarket and very difficult for the original subscribers to claim compensation for misstatements in the offering prospectus. Similar to the situation in Germany, the law had reached a point where the courts had introduced certain innovations in response to changing economic conditions, but traditional legal doctrines displayed considerable inertia. In particular, the century-old institutions of deceit and actio doli channelled legal reasoning in ways that made it difficult for the courts to innovate where innovation was needed most: in modifying the requirement that investors show dishonesty on the part of the directors. More was needed, but in both countries, legal mechanisms that were more finely calibrated to take account of the function of prospectuses and the informational asymmetry between investors and issuers were only introduced towards the end of the century in the form of codified prospectus liability provisions. ${ }^{140}$ These mechanisms, as well, did not prove effective in either country, because the threshold for recovery by investors continued to be high. ${ }^{141}$

\footnotetext{
${ }^{137}$ Derry v Peek (1889) LR 14 App Cas 337 at 374. The defendant did not, however, need to have intended the claimant to suffer a loss.

${ }^{138}$ Ibid. 368.

${ }^{139}$ See notes $124-125$ above.

${ }^{140}$ UK Directors Liability Act 1890, 53 \& 54 Vict., c. 64, s. 3(1); German Stock Exchange Act 1896, ss. 43-44.

${ }^{141}$ I compare the UK and German prospectus liability provisions in detail elsewhere, see Carsten Gerner-Beuerle, 'Disclosure Regulation and the Rise of Capital Markets: $19^{\text {th }}$ Century Britain and Germany Compared' in Robin Huang and Nicholas Howson (eds.), Enforcement of Corporate and Securities Law: China and the World (CUP ***
} 


\section{DIVERGING PATHS: FORMATION LAW}

\section{Germany: 'Investing in shares is always risky' ${ }^{142}$}

As we have seen, disclosure was used in both Germany and the United Kingdom as a substitute mechanism for the lack of state control when the concession system was replaced with a system of incorporation by registration. In both countries, disclosure obligations were relatively fragmentary and did not impose undue regulatory burdens on companies. The same could be said initially about the formation regimes that applied under the newly introduced liberalised laws. The steps that had to be taken pursuant to the German Companies Act of $1870^{143}$ to establish a company were simple. The act required the drawing up, filing and publication of the memorandum of association with a specified content; ${ }^{144}$ the filing of additional information with the registrar of companies confirming, inter alia, that all of the company's share capital had been subscribed and at least ten percent of the amount owed by the shareholders was paid up; ${ }^{145}$ and the registration of the company. ${ }^{146}$ Considerations in kind were permissible without independent valuation; ${ }^{147}$ minimum par value was fixed at a level that was lower than under the previous Prussian legislation, while not being insignificantly low; ${ }^{148}$ and the act left considerable scope for contractual freedom in fashioning the company's governance architecture.

This regime was reformed fundamentally in the wake of the financial crisis of $1873 .{ }^{149}$ Interestingly, even though the events of 1873 can be considered the first major stock

\footnotetext{
${ }^{142}$ Stenographische Berichte über die Verhandlungen des Reichstages, 5. Legislatur-Periode, IV. Session 1884 [Stenographic protocols of the proceedings of the Reichstag, $5^{\text {th }}$ parliamentary term, session IV 1884], vol. 3, document no. 21, p. 248. Most of the document (except appendix B containing statistical information) is reprinted in Schubert and Hommelhoff, n 29 above, 387-559. Page numbers here refer to the original Reichstag document. All translations are mine. The quote continues: 'The savings of the small investors, acquired laboriously and constituting maybe their only assets after long years of work, must be invested safely. ... A return on investment in shares is often expected to be found ... in speculation, the sale of the security at a higher price. The small investor is not capable of choosing the right moment for such a sale, and neither is he able to assess independently the situation of the stock corporation or exercise his rights as a shareholder. Circles that must be assumed to lack these abilities should be prevented from investing in stock corporations.' See also the text to n 160-162 below.

${ }^{143}$ Act of 1870, n 20 above.

${ }^{144}$ Ibid. arts. 209, 210.

${ }^{145}$ Ibid. art. 210a.

${ }^{146}$ Ibid. art. 211.

${ }^{147}$ Ibid. art. 209b.

${ }^{148}$ The minimum value was 50 thalers in the case of registered shares and 100 thalers in the case of bearer shares, ibid. 654 .

${ }^{149}$ Text to notes 27-31 above.
} 
exchange crash in Germany, the legislator reacted initially with circumspection. The Higher Commercial Court of the Reich in its study of 1877 took pains to emphasise that the fraudulent and speculative practices were not primarily a consequence of the Companies Act of 1870, the basic principles of which the Court found to be sound, but of the credulity of the public and their naïve faith in indefinitely rising stock prices and sustained economic growth. ${ }^{150}$ The Federal Council of the Reich also cautioned that it was not advisable to engage in legislative activity while public opinion was still affected by the recent crisis and pointed out that existing legal mechanisms were sufficient to address abuses if applied forcefully. ${ }^{151}$ Nevertheless, a few years later the Federal Council, mainly upon the instigation of Prussia and against the opposition of the more liberal northern German states, resolved to suggest a comprehensive reform of the 1870 Act. ${ }^{152}$ The ministry of justice did not pursue the reforms as a high priority. It was of the view that the excesses of the Gründerzeit, the years after the abolishment of the concession system, had abated and the effects of any legislative reform on the system of free enterprise that had been ushered in by the 1870 Act should be considered carefully before any concrete steps were taken. ${ }^{153}$ Eventually, however, the government produced a draft law ${ }^{154}$ that was adopted with some amendments in $1884,{ }^{155}$ in spite of attracting fierce criticism from both conservative and liberal circles. ${ }^{156}$

${ }^{150}$ Reichsoberhandelsgericht, $\mathrm{n} 29$ above, 6-7. The chambers of commerce of Hamburg and Bremen expressed a similar view, Werner Schubert, 'Die Entstehung des Aktiengesetzes vom 18. Juli 1884' in Schubert and Hommelhoff, n 29 above, 1, 8.

${ }^{151}$ Bericht des Ausschusses für Justizwesen [Report of the Justice Committee] of 9 June 1874, Bundesratsdrucksache Nr. 78 von 1874 [Journal of the Federal Council, no. 78 of 1874], reprinted in Werner Schubert (ed.), Materialien zur Entstehungsgeschichte des BGB: Einführung, Biographien, Materialien (De Gruyter 1978), 186, 196-197. The importance of implementing reforms dispassionately and not under the impression of a crisis was also stressed by commentators, see e.g. Felix Hecht, 'Zur Reform des Aktiengesellschaftsrechts', Volkswirthschaftliche Zeitfragen, vol. 4, issue 25 (1882), p. 32. It seems that these sentiments reflect enduring questions about the necessity of regulatory intervention in the aftermath of financial crises or scandals that resurface to this day, see Roberta Romano, 'The Sarbanes-Oxley Act and the Making of Quack Corporate Governance' (2005) 114 Yale L.J. 1521, 1591-1594 and passim.

${ }^{152}$ Resolution of the Federal Council of 13 March 1877, cited in Schubert, n 150 above, 15. It is a telling example of the sometimes random manner in which reform initiatives evolve that the resolution of the Federal Council in favour of regulatory intervention garnered sufficient support not because of the delegates' conviction of the measure's necessity, but, as was claimed, because of a desire on the part of the smaller states to accommodate Prussia, ibid. 15. The opposition particularly of the three Hanseatic cities Bremen, Hamburg and Lübeck continued until the adoption of the final law in 1884. The cities' representatives raised concerns regarding some provisions of the Act of 1884 that imposed a high standard of responsibility on directors and intermediaries for compliance with the formation rules, arguing that this would disincentivise the most qualified and respectable persons becoming involved in incorporations. However, in the event, Bremen and Lübeck refrained from voting against the draft law because, as they declared, they wished to respect the resolution of the Federal Council of March 1877, ibid. 35-36.

${ }^{153}$ Ibid. 20-21.

154 Entwurf eines Gesetzes, betreffend die Kommanditgesellschaften auf Aktien und die Aktiengesellschaften [Proposal for an Act Concerning Limited Partnerships by Shares and Joint Stock 
The policy goals of the reform were twofold: The act sought to strengthen the position of investors and protect them against the rapid, and at times fraudulent, incorporation of companies that did not always carry on a viable business. At the same time, the law pursued somewhat diffuse macroeconomic goals. It was believed that the incorporation of a large number of companies gave rise to overproduction and that the law should ensure that only socially useful firms were incorporated. ${ }^{157}$ On the other hand, the legislator acknowledged that it could not be the role of the law to differentiate between economically productive and less productive uses of the corporate form. ${ }^{158}$ Instead of imposing some form of merit requirements, the legislator pursued the reform goals, inter alia, by introducing higher minimum legal capital requirements and more stringent rules on capital contributions. ${ }^{159}$

First, and most importantly, the minimum par value of shares was increased to 1,000 marks. ${ }^{160}$ This increase was explicitly seen as a central investor protection mechanism and shows the paternalistic nature of the reform. While the policy makers recognized that only the investor's vigilance could protect effectively against deceit and improvidence, ${ }^{161}$ they evidently did not have much faith in the ability of the 'small investor' (the 'kleine Mann' or 'kleine Kapitalist') to assess the value of an investment opportunity. The legislative memorandum accompanying the 1884 Act explained that the savings of this class of investors, 'acquired laboriously and constituting maybe their only assets after long years of

Corporations] of January 1882. The draft law was based on a detailed report of a commission of businessmen and legal experts, Verhandlungen der Aktienrechtskommission [Proceedings of the commission on stock corporation law] from 24 March 1882 to 8 April 1882. Both documents are reprinted in Schubert and Hommelhoff, n 29 above, 263-287 and 288-386, respectively.

${ }^{155}$ Act of 1884, n 32 above.

${ }^{156}$ Conservative circles criticised that the law did not go far enough in reigning in the use and abuse of the corporate form. See, for example, Franz F. Perrot, member of parliament for the conservative party, who claimed that carrying on business in the form of the joint stock corporation and raising capital in financial markets led to a 'deterioration of the morals at virtually all levels of society', 'Ein parlamentarisches Votum über das Aktienwesen’ in Wilhelm Frommel and Alexius B.I.F. Pfaff (eds.), Sammlung von Vorträgen für das deutsche Volk, vol. 11 (C. Winter 1884). The liberal side, on the other hand, alleged, for example, that the reform law 'preached on every page ... and between every line distrust of the active, enterprising businessman', Adelbert Delbrück, 'Bemerkungen zu dem Entwurf eines Gesetzes betreffend Commanditgesellschaften auf Actien und Actiengesellschaften', Volkswirthschaftliche Zeitfragen, vol. 5, issue 39 (1883), p. 38. For an overview of further critical interventions see Schubert, n 150 above, 42-50.

${ }^{157}$ See the references in Schubert, n 150 above, 49.

${ }^{158}$ Stenographic protocols, n 142 above, 242.

${ }^{159}$ Ibid. 245.

${ }^{160}$ General German Commercial Code, as amended, art. 207a. The requirement applied to both registered and bearer shares, with an exception for registered shares with restricted transferability, which could be issued with a nominal value of not less than 200 marks. The minimum nominal value remained unchanged until 1923, when it was reduced to 100 marks (Goldbilanzverordnung of 28 December 1923, RGB1. I 1923, p. 1253, ss. 10(2), 17(2)).

${ }^{161}$ Stenographic protocols, n 142 above, 245. 
work', should be placed in save investments, such as government bonds or interests in cooperatives. The small savers should, accordingly, be prevented from accessing the capital markets altogether. ${ }^{162}$ Further, the legislator expected the high nominal value to have a salutary effect on the conduct of sophisticated investors as well. Because of the larger sums invested, the investors would be incentivized to participate more actively in the affairs of the company, and the general meeting, consisting of a less widely dispersed body of shareholders, would become a more effective control organ. ${ }^{163}$

Second, registration of the company required that all shares were subscribed and, in the case of contributions in cash, at least one fourth of the nominal value and the premium in full be paid up. ${ }^{164}$ The subscribers were not allowed to set off their obligations against any claims they might have against the company. ${ }^{165}$ Share certificates could be issued only after the shares had been paid up in full, and interim certificates issued to bearer were prohibited. ${ }^{166}$ The subscribers and all subsequent acquirers of shares were liable to the company for any amount outstanding on the shares. ${ }^{167}$ If contributions were made in kind, the founders had to sign a declaration setting out why the shares constituted, in their view, adequate consideration. ${ }^{168}$ The members of the management and supervisory board had to verify compliance of the formation process with the legal requirements. In addition, in some cases, the law prescribed an external valuation, in particular where the members of the management or supervisory board were also the founders or had transferred property to the company. ${ }^{169}$ Finally, the 1884 Act imposed joint and several civil liability and criminal sanctions on founders and directors who made incorrect statements about subscriptions or contributions, for example if they overstated the value of a contribution in kind or declared that the nominal value and premium had been paid up, where this was not in fact the case. ${ }^{170}$ Importantly, the law shifted the burden of proof for civil responsibility to the founders, who had to show that

\footnotetext{
162 Ibid. 248.

163 Ibid.

${ }^{164}$ General German Commercial Code, as amended, arts. 209e(1), 210.

${ }^{165}$ Ibid. arts. 184c, 219(2).

${ }^{166}$ Ibid. art. $215 \mathrm{c}$.

${ }^{167}$ The liability was not joint and several; rather, prior shareholders were liable if the amount could not be obtained from the last shareholder(s), arts. 184b, 219(2).

${ }^{168}$ Ibid. art. $209 \mathrm{~g}$.

${ }^{169}$ Ibid. art. 209 h.

${ }^{170}$ Ibid. arts. 213a-c, 249a.
} 
they did not know and, exercising the care of a reasonably diligent businessman, could not have known that the relevant declaration was incorrect or incomplete. ${ }^{171}$

These amendments tackled directly what were perceived to be the most egregious defects of the Companies Act of 1870. The old law had not envisaged any external control of the formation process or the valuation of contributions in kind, with the consequence that the founders had often enriched themselves to the detriment of outside investors and creditors, and the capital had not been paid up. ${ }^{172}$ Another problem highlighted by the reform was the fact that subscribers had been only liable for $40 \%$ of the nominal value of the shares, and the company could be given authority in the articles to release the shareholders from the remainder of their obligations. ${ }^{173}$ This authority was intended as an exceptional provision, but it was observed that it had become the rule in practice and had been used widely in order to release subscribers in situations where the shares had lost much of their value. ${ }^{174}$

\section{United Kingdom: 'I am arguing in favour of human liberty, ${ }^{175}$}

In contrast to Germany, the UK formation regime remained relatively stable since the introduction of incorporation by registration in $1844,{ }^{176}$ in spite of several financial crisis and scandals that occurred over the course of the $19^{\text {th }}$ century. The Act of 1844 established a registrar of joint stock companies and required only the filing of certain particulars for the formation of companies. ${ }^{177}$ It further set out the rights and powers of the shareholders and directors, including rules on related-party transactions, ${ }^{178}$ and contained detailed provisions on the company's books and records. ${ }^{179}$ On the other hand, the company's capital structure was only lightly regulated. The act did not provide for any minimum legal capital or minimum nominal value of the shares. Shareholders could make their contributions in cash or kind. The

\footnotetext{
${ }^{171}$ Ibid. art. 213a(3). With respect to other defendants, for example the directors, the burden of proof was not reversed, arts. $213 \mathrm{~b}$, c. For a detailed analysis of the liability of the founders, see Lehmann, $n$ 90 above, 457-472.

${ }^{172}$ Stenographic protocols, n 142 above, 260, 266-267.

${ }^{173}$ Act of 1870, n 20 above, art. 222.

${ }^{174}$ Stenographic protocols, n 142 above, 254.

${ }^{175}$ Speech given by Robert Lowe on occasion of the introduction of the Joint Stock Companies Act 1856 in the House of Commons. For the full quote, see n 21 above.

${ }^{176}$ See text to notes 37-39 above.

${ }^{177}$ Joint Stock Companies Act 1844, s. 4. See text to n 39 above.

${ }^{178}$ Ibid. s. 29.

${ }^{179}$ Ibid. ss. 32-43.
} 
act required disclosure of the nature and value of the contribution, but in-kind contributions did not need to be valued independently. ${ }^{180}$

In spite of its progressive nature, the 1844 Act was not seen as unambiguously successful, especially because it did not resolve the problem of how to limit the liability of investors who had neither the incentive nor the ability to supervise the company's management. ${ }^{181}$ This question triggered an intense public debate about the advantages and risks of limited liability, ${ }^{182}$ which was eventually resolved in favour of introducing limited liability with the adoption of the Limited Liability Act of $1855 .{ }^{183}$ The act sought to chart a careful course between those who championed limited liability as a central tenet of free enterprise and economic development, and those who were concerned that it would encourage improper speculation. The act provided for several safeguards designed to protect creditors and the public in general, notably by requiring that shares were of a nominal value of not less than ten pounds, at least three fourths of the nominal capital was subscribed, and shareholders had paid up at least $20 \%$ of the subscribed amount before registration, which was to be attested by a statutory declaration of the promoters. ${ }^{184}$ In addition, the act introduced certain capital maintenance requirements. The directors were jointly and severally liable for the debts of the company if they paid out dividends knowing that the company was insolvent ${ }^{185}$ and the company had to be wound up if three fourths of the subscribed capital was lost. ${ }^{186}$ Finally, appointment of at least one auditor required approval of the Board of Trade. ${ }^{187}$

The Limited Liability Act 1855 was revoked less than a year after its enactment, together with the Act of 1844 and other amending acts, and the law was consolidated by the Joint Stock Companies Act $1856 .{ }^{188}$ This act, more than any other, was influenced by the ideas of laissezfaire. ${ }^{189}$ It simplified the process of registration and moved a number of previously mandatory

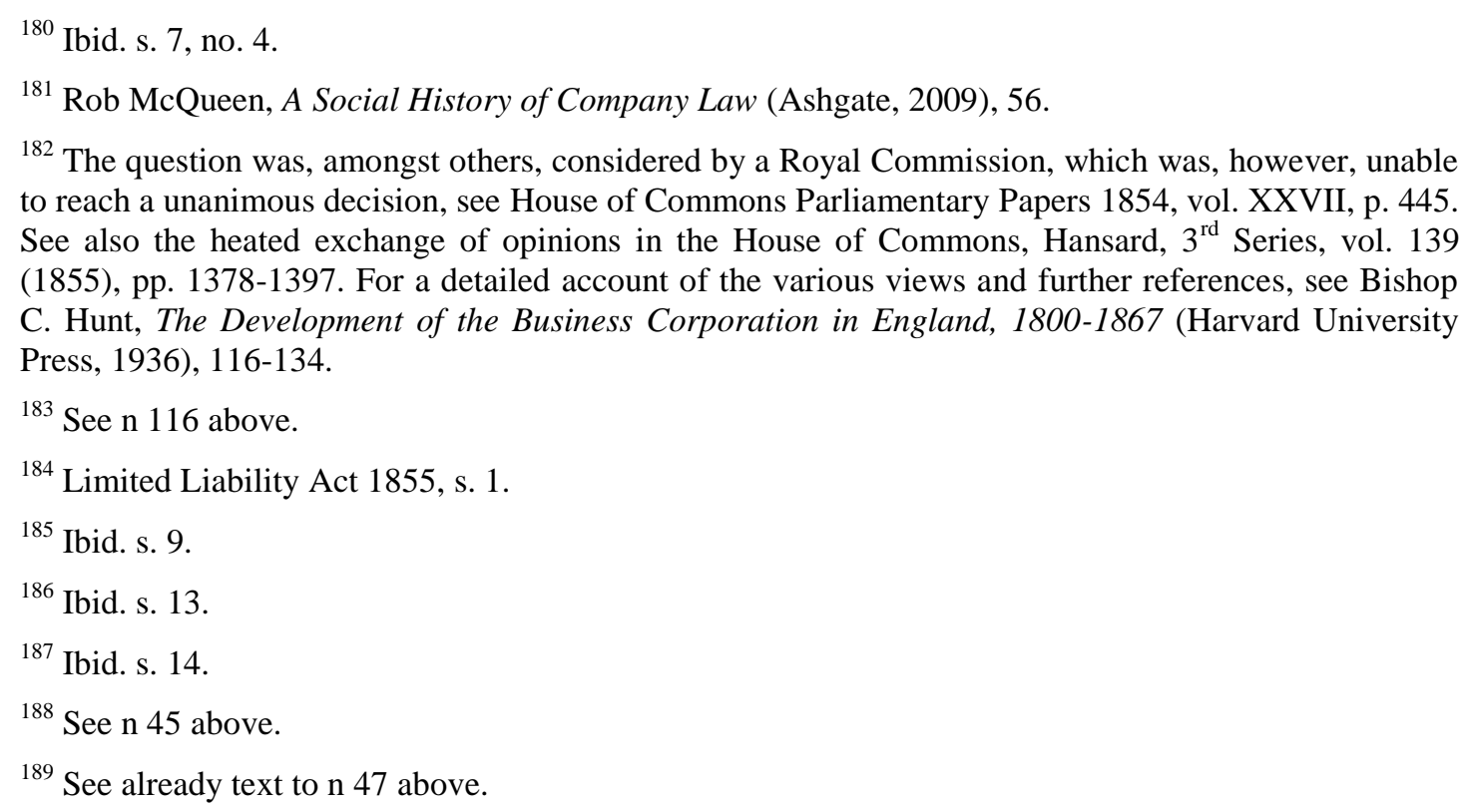


provisions to the model articles of association. ${ }^{190}$ Freedom of contract was, therefore, accorded a salient role in the formation of companies. The safeguards that the Limited Liability Act 1855 had stipulated as the 'price' of limited liability were repealed almost in their entirety. ${ }^{191}$ The 1856 Act did not prescribe a minimum nominal value of shares, a minimum percentage of the subscribed capital to be paid up, or any statutory declaration of the promoters as to the paid-up amount. The binding part of the act contained only two provisions on capital requirements and capital maintenance, apart from rules mandating disclosure. The directors were still liable for dividend payments made in knowledge of the company's insolvency ${ }^{192}$ and the loss of three fourths of the company's capital entailed its winding up. ${ }^{193}$

The two other main companies acts that were adopted until 1913, the Companies Act $1862^{194}$ and the Companies (Consolidation) Act $1908,{ }^{195}$ as well as their various amending acts, left the main system of incorporation and registration established by the 1856 Act intact. The successive acts introduced new distinctions, for example between private and public companies, ${ }^{196}$ and the rules became more detailed, but incorporation continued to be regulated in a permissive manner, requiring simply the filing of the memorandum of association. ${ }^{197}$ Further rules governing the raising of capital were not very onerous, and the risk of liability for promoters and subscribers was limited. Amendments merely stipulated that the minimum amount payable before allotment should not be less than five percent ${ }^{198}$ and the amount paid in cash or the nominal value of the shares allotted against contributions in kind, and any

\footnotetext{
${ }^{190}$ See text to $\mathrm{n} 45$ above. The model articles were laid down in Table B of the Schedule to the 1856 Act.

191 The 1856 Act did, however, introduce a new shareholder protection mechanism. Upon the application of one fifth of the shareholders, the Board of Trade was authorised to appoint an inspector to examine the company's books and records, request information from the company's officers and agents, and produce a report to be forwarded to the applicant shareholders, Joint Stock Companies Act 1856, ss. 48-52. This mechanism was considered to be more effective 'than any restrictions that could be imposed upon the formation of companies', Hansard, $3^{\text {rd }}$ Series, vol. 140 (1856), p. 135.

192 Joint Stock Companies Act 1856, s. 14.

${ }^{193}$ Ibid. s. 67(5). This provision was no longer contained in the Companies Act 1862, s. 79.

${ }^{194} 25$ \& 26 Vict., c. 89.

1958 Edw. 7, c. 69.

196 Companies Act 1907, 7 Edw. 7, c. 50, s. 37. Private companies were, for example, exempted from publishing a prospectus or statement in lieu of prospectus, s. 1(5), and filing an audited balance sheet with the registrar of companies, s. 21.

${ }^{197}$ See, e.g., Companies (Consolidation) Act 1908, ss. 15, 16(1).

198 Companies Act 1900, s. 4(3) (applicable to offers to the public); Companies Act 1907, s. 1(3) (requirement extended to companies that do not issue any invitation to the public to subscribe for shares); combined in Companies (Consolidation) Act 1908, s. 85(3), (7).
} 
contract of sale or for services regarding contributions in kind, should be filed with the registrar. $^{199}$

This lenient approach was confirmed by case law. The courts utilized general principles of company law, namely the ultra vires doctrine, to decide that a company had no power to issue shares as fully paid-up without receiving consideration equivalent to the nominal value of the shares. ${ }^{200}$ If consideration is given in kind, the question, of course, becomes how to value the contribution to ascertain whether it is 'equivalent' to the nominal value of the shares issued. In the famous case In Re Wragg, where property given in consideration for shares was overstated by about $80 \%,{ }^{201}$ it was held that a court would not go behind the contract and examine whether the consideration was valued correctly unless the claimant showed fraud: 'Provided a limited company does so honestly and not colourably, ... agreements by limited companies to pay for property or services in paid-up shares are valid and binding on the companies and their creditors' ${ }^{202}$ The reasoning of the Court of Appeal makes it clear that, save in exceptional circumstances, ${ }^{203}$ the courts will not interfere with entrepreneurial activity or substitute their own judgment for that of the market actors in business matters:

It is not law that persons cannot sell property to a limited company for fully paidup shares and make a profit by the transaction. We must not allow ourselves to be misled by talking of value. The value paid to the company is measured by the price at which the company agrees to buy what it thinks it worth its while to acquire. Whilst the transaction is unimpeached, this is the only value to be considered. $^{204}$

The courts were, of course, aware of the conflict of interest that characterises transactions in which shareholders transfer property or render services to the company for fully paid-up shares. ${ }^{205}$ But they acknowledged that the law as it stood did not impose any constraints on

\footnotetext{
${ }^{199}$ The registration requirement was added by the Companies Act 1867, 30 \& 31 Vict., c. 131, s. 25, in reaction to widespread abuses after the courts had clarified that payment for shares could be made in kind, see, e.g., In re China Steamship and Labuan Coal Co. (1868-69) L.R. 4 Ch. App. 772 (Drummond's Case). It was retained in subsequent acts, see Companies Act 1900, s. 7(1); Companies (Consolidation) Act 1908, s. 88(1).

${ }^{200}$ In Re Eddystone Marine Insurance Co. [1893] 3 Ch. 9, 14 per Wright J.; In Re Wragg, Ltd. [1897] 1 Ch. 796, 808 per Vaughan Williams J.

201 [1897] 1 Ch. 810.

202 Ibid. 830 per Lindley L.J.

${ }^{203}$ Where the transaction is 'colourable or illusory', ibid. 835 per A.L. Smith L.J.

${ }^{204}$ Ibid. 831 per Lindley L.J.

${ }^{205}$ See the considerations of Lindley L.J. ibid. 831-832.
} 
such transactions, and the only mechanism to protect the public was the requirement to register the agreement between the company and the shareholder. ${ }^{206}$

\section{The importance of formation law}

The German reforms of 1884 had a clear effect on the ease of formation of joint stock corporations. As intended by the legislator, the high minimum par value of shares effectively excluded a large proportion of the population from subscribing to equity issues. An examination of the income distribution in Germany at the time may serve to illustrate the impact of the nominal value requirement. According to Prussian income tax data from 1881, $72.54 \%$ of all taxpayers had an annual income of 660 marks or less, $21.41 \%$ an income of $661-1,500$ marks, $4.11 \%$ earned 1,501-3,000 marks, and 1.94\% more than 3,000 marks. ${ }^{207}$ Even if these figures are increased by one quarter to control for underreporting, as suggested by some contemporary commentators, $45.07 \%$ of taxpayers had an average annual income of 647 marks, a further $37.63 \%$ an average income of 1,536.3 marks, and the remaining $17.3 \%$ an average income of $9,271.1$ marks. ${ }^{208}$

The strict rules on formation and capital contributions made incorporations more costly, particularly by requiring an external audit in specified cases, and entailed a higher risk of liability for founders and others involved in the formation process. It is, therefore, reasonable to assume that the joint stock corporation became comparatively less attractive as a legal vehicle to pursue business operations, and the stock market less relevant for the raising of finance. Indeed, while incorporations did not decrease in absolute numbers, ${ }^{209}$ they decreased in relative terms. ${ }^{210}$ In addition, it has been observed that the ownership structure of

\footnotetext{
${ }^{206}$ Ibid. 830: 'The Legislature in 1867 appears to me to have distinctly recognised such [as set out in the quote above, text to $\mathrm{n} 204$ ] to be the law, but to have required in order to make such agreements binding that they shall be registered before the shares are issued.'

${ }^{207}$ Ernst Engel, 'Der Werth des Menschen', Volkswirthschaftliche Zeitfragen, vol. 5, issue 37 (1883), p. 16.

${ }^{208}$ Ibid. 17. For further comprehensive income data see Walter G. Hoffmann, Das Wachstum der deutschen Wirtschaft seit der Mitte des 19. Jahrhunderts (Springer 1965), 85-102 (distinguishing between income from labour and capital).

${ }^{209}$ The number of joint stock companies, which was around 1,000 in the mid-1870s, increased to more than 2,000 in the second half of the 1880s and continued to rise to c. 5,500 by 1913, Deutsche Bundesbank, n 5 above, 294; Engel, n 5 above, 458-467. For a breakdown of stock corporations in operation by German state and their aggregate capital, see Ewald Moll, Die Rentabilität der Aktiengesellschaft (G. Fischer 1908), 8 (reproducing data from the Imperial Statistical Office for 1906, Statistisches Jahrbuch für das deutsche Reich 1908, p. 328, which found a total of 5050 stock corporations in Germany with an aggregate capital of 13,767.7 million marks). An evaluation of additional sources and a summary of the data from 1800-1914 is given by Fohlin, 'History', n 9 above, 226.

${ }^{210}$ For data, see the references in $\mathrm{n} 11$ above.
} 
companies changed. Banks and industrial corporations became more important as providers of equity capital, and as a result economic concentration increased. ${ }^{211}$ For small and mediumsized enterprises, the form of the public stock corporation was not suitable, and demands for a less onerous regulatory framework were voiced. ${ }^{212}$ These calls were heeded in 1892 with the adoption of the law on the limited liability company, which provided for a form of business association benefitting from limited liability without the demanding formation regime of the public stock corporation, and which placed greater emphasis on contractual freedom in shaping the governance structure of the company. ${ }^{213}$ On the other hand, the design of the limited liability company's share capital prevented the founders from offering shares to the public or trading them on capital markets, ${ }^{214}$ thus forcing an important subset of German industrial enterprises to take recourse to other forms of financing, especially retained earnings and bank loans.

A comparison of the diffusion of German public stock corporations with that of their counterparts in other European countries also highlights the different path that the German corporate landscape had taken by the end of the $19^{\text {th }}$ century. The number of joint stock companies incorporated in Germany was relatively low, around 5,000 at the turn of the century with an aggregate paid-up capital of 685 million pounds sterling, ${ }^{215}$ compared with more than 40,000 in the UK with an aggregate capital of 2,000 million pounds sterling. ${ }^{216}$ On the other hand, the average capital of a German corporation was almost three times higher than that of UK companies and in fact higher than in any other European country except Austria and Russia. ${ }^{217}$ The considerably larger number of smaller incorporated businesses in

\footnotetext{
${ }^{211}$ See the references in $\mathrm{n} 10$ above.

${ }^{212}$ For an overview of the contemporary discussion, see Claus Ott, Recht und Realität der Unternehmenskorporation (Mohr Siebeck 1977), 107-109, with references.

${ }^{213}$ Gesetz, betreffend die Gesellschaften mit beschränkter Haftung [Limited Liability Companies Act] of 20 April 1892, RGB1. 1892, p. 477.

${ }^{214}$ In particular, the law provided that each member could only take one share (s. 5(2) Limited Liability Companies Act 1892), the sale of fractional shares required authorisation by the company (s. 17(1)), and shares could only be transferred by notarised contract (s. 15(3)). For these reasons, this type of company is often translated as 'private limited company' into English.
}

215 The term 'joint stock company' (taken from Michie, n 3 above, 52) refers here to the Aktiengesellschaft, i.e. the public company.

${ }^{216}$ Michie, n 3 above, 52, relying on data from Augustus D. Webb, The New Dictionary of Statistics (Routledge 1911), 145. For detailed data see also Ron Harris, 'The Private Origins of the Private Company' (2013) 33 O.J.L.S. 339, 343-352.

${ }^{217}$ In addition to Austria, Germany, Russia, and the UK, the relevant sample consisted of France, Holland, Belgium, Denmark, Italy, Hungary, Switzerland, and Finland. According to Michie's calculations, the average paid-up capital of German corporations in 1906 was 135,349 pounds sterling, and that of UK joint stock companies 48,786 pounds sterling. The German figures include the Reichsbank, but they do not change significantly if the Reichsbank is excluded. The relevant data can be obtained from Webb, n 216 above, 146. The number of joint stock companies (excluding the 
the UK can of course be explained with the fact that the figures comprise both what we would now call public and private companies. However, arguably, this does not detract from the significance of the comparison. A formal distinction between private and public companies was introduced into English company law only in $1907,{ }^{218}$ and private companies could be transformed into public companies relatively easily by passing a special resolution to this effect and filing a statement in lieu of prospectus with the registrar. ${ }^{219}$ The importance of the German amendments can be seen in the decision to condition access to the capital markets not on compliance with particular disclosure obligations, such as the publication of a prospectus or statement in lieu of prospectus, but on the implementation of a capital structure fundamentally different from, and more costly than, that of other forms of business association. The legislator of 1884 was conscious of the choice between more stringent transparency requirements and a more demanding formation regime. The lawmakers discussed the English regulatory approach centred on a document informing the public in a fairly detailed manner about the company and the offering, which they referred to as 'prospectus theory', and rejected it because they believed the repetition of past financial scandals could only be avoided if the solidity of corporate issuers, and hence their capital structure, were improved. ${ }^{220}$ The formation regime thus adopted, it is submitted, represents the main difference between the German and British regulatory environment. It had farreaching ramifications for the development of the corporate landscape in Germany that continue to be felt to this day, as a significant section of economic activity is pursued in the form of the limited liability company, which is effectively excluded from the equity capital markets, and the public stock corporation was reserved for large, capital intensive undertakings. ${ }^{221}$

Reichsbank) is given as 5,060 and their nominal capital as 680 million pounds sterling, resulting in an average nominal capital of 134,387 pounds sterling.

${ }^{218}$ The Companies Act 1907 defines 'private company' in s. 37(1) as 'a company which by its articles - (a) restricts the right to transfer its shares; and (b) limits the number of its members (exclusive of persons who are in the employment of the company) to fifty; and (c) prohibits any invitation to the public to subscribe for any shares or debentures of the company.' Without using the terms public and private company, earlier acts distinguished between companies offering shares to the public and those that did not intend to do so, exempting the latter from certain requirements, see e.g. Companies Act 1900, s. 6(7).

${ }^{219}$ Companies Act 1907, s. 37(2).

${ }^{220}$ Stenographic protocols, n 142 above, 267. For a contemporary and comparative discussion of prospectus theory, see Lehmann, n 90 above, 331-332. It has been shown that the reforms had indeed the effect of improving the survival rate of some firms that listed on the Berlin stock exchange, Burhop, Chambers, and Cheffins, $\mathrm{n} 9$ above, 24-26.

${ }^{221}$ The transfer of shares in the private limited liability company must still be notarised, s. 15(3), (4) Gesetz betreffend die Gesellschaften mit beschränkter Haftung [Limited Liability Companies Act] of 20 May 1898, RGB1. 1898, p. 846. The notarisation requirement serves primarily to impede the emergence of an active (and potentially speculative) trade in shares of this type of company, as 


\section{CONCLUSION}

A tentative answer to the question whether 'law matters ${ }^{222}$ for financial development may refer to the above analysis in order to point out that the identification of channels of influence requires a granular analysis of individual legal institutions, and that these channels are likely to be very different for different legal mechanisms. As far as the two countries and the period examined here are concerned, certain patterns emerge. There is no evidence that Britain's capital markets were more developed because British investors were 'armed ... with the best information possessed by investors anywhere ${ }^{, 223}$ and because they had more effective liability provisions at their disposal. In both countries, the level of disclosure regulation was broadly comparable, and in both countries it evolved incrementally and as a response to changing market conditions. Over the course of the $19^{\text {th }}$ century, the offering prospectus was reconceptualised as a tool to ensure market transparency, rather than a communication with the sole purpose of announcing the establishment of a company and selling shares in that company. Similarly, incorrect disclosures were gradually no longer assessed through a saleof-goods and failure-of-consideration lens. Instead, the courts focused on the marketconditioning function of prospectuses and asked whether facts that were material to an informed investment decision were omitted or presented incorrectly. ${ }^{224}$

The developmental path of formation law was fundamentally different. It was aligned in both countries only until 1884, when Germany left the path of liberal reform that it had followed since the abolishment of the concession system and introduced a stringent set of capital requirements. Furthermore, regulatory reform in this area was characterised not so much by incremental evolution as by comprehensive legislative packages that were intended to place the corporate economy on a substantially reformed regulatory footing, first in 1844 (in the case of the UK) and 1870 (Germany) through introduction of a system of registration by incorporation, and then in 1856 (UK) and 1884 (Germany) by respectively liberalising and restricting the applicable regime and organisational choice.

explicitly acknowledged by the legislator, see the explanatory notes to the 1898 Act, Stenographischer Bericht über die Verhandlungen des Reichstages, 8. Legislaturperiode, I. Session 1890/1892, 5. Anlagenband [Stenographic protocols of the proceedings of the Reichstag, $8^{\text {th }}$ parliamentary term, session I $1890 / 1892,5^{\text {th }}$ supplementary volume], 3724, 3729. The motives are also discussed in Bundesgerichtshof [Federal Court of Justice], decision of 5 November 1979, Neue Juristische Wochenschrift 1980, 1100.

${ }^{222}$ Rafael La Porta, Florencio Lopez-de-Silanes, and Andrei Shleifer, 'What Works in Securities Laws?' (2006) 61 J. Fin. 1, 2.

${ }^{223}$ Sylla and Smith, n 6 above, 179.

${ }^{224}$ With a few exceptions, liability under British and German law still required a showing of dolus, which was a legacy of the available common law causes of action, but it is evident that the changed economic conditions influenced the reasoning of the courts. 
It is a question for future research whether these findings can be generalised. In order to do so, it would be necessary to extend the analysis to other potentially explanatory legal and nonlegal factors, and it would be worth exploring whether and how patterns of mutual influence between law and finance change over longer periods of time and in other countries. In any case, we can already conclude, as opposed to what has been argued in the literature, ${ }^{225}$ that there is no reason to assume that the common law is inherently superior in providing for a regulatory environment conducive to financial development. As we have seen, a regulatory 'superstructure' dealing with market transparency emerged in both the United Kingdom and Germany in the $19^{\text {th }}$ century in similar forms. The divergence in the menu of organisational choice available for doing business, on the other hand, cannot be attributed to characteristics of common law or civil law, but the prevalent political climate of the day and the balance of market-liberal and conservative political forces in the relevant decision-making bodies. ${ }^{226}$

\footnotetext{
${ }^{225}$ See the references in $n 6$ above.

${ }^{226}$ See, for example, n 152 above.
} 